\title{
The ecology, distribution, conservation and management of large
}

\section{old trees}

David Lindenmayer,"* and William F. Laurance ${ }^{2}$

${ }^{1}$ Fenner School of Environment and Society, The Australian National University, Canberra, Australian Capital Territory 2601, Australia

${ }^{2}$ Centre for Tropical Environmental and Sustainability Science (TESS) \& College of Science and Engineering, James Cook University, Cairns, Queensland 4878, Australia

*Author for correspondence (E-mail: david.lindenmayer@anu.edu.au; Tel.: +61 2 $61250654)$. 


\section{ABSTRACT}

Large old trees are some of the most iconic biota on earth and are integral parts of many terrestrial ecosystems including those in tropical, temperate and boreal forests, deserts, savannas, agro-ecological areas, and urban environments. In this review, we provide new insights into the ecology, function, evolution and management of large old trees through broad cross-disciplinary perspectives from literatures in plant physiology, growth and development, evolution, habitat value for fauna and flora, and conservation management. Our review reveals that the diameter, height and longevity of large old trees varies greatly on an inter-specific basis, thereby creating serious challenges in defining large old trees and demanding an ecosystem- and species-specific definition that will only rarely be readily transferable to other species or ecosystems. Such variation is also manifested by marked inter-specific differences in the key attributes of large old trees (beyond diameter and height) such as the extent of buttressing, canopy architecture, the extent of bark micro-environments and the prevalence of cavities.

We found that large old trees play an extraordinary range of critical ecological roles including in hydrological regimes, nutrient cycles and numerous ecosystem processes. Large old trees strongly influence the spatial and temporal distribution and abundance of individuals of the same species and populations of numerous other plant and animal species. We suggest many key characteristics of large old trees such as extreme height, prolonged lifespans, and the presence of cavities - which confer competitive and evolutionary advantages in undisturbed environments - can render such trees highly susceptible to a range of human influences. Large old trees are vulnerable to threats ranging from droughts, fire, pests and pathogens, to logging, land clearing, landscape fragmentation and climate change. Tackling 
such diverse threats is challenging because they often interact and manifest in different ways in different ecosystems, demanding targeted species- or ecosystem-specific responses.

We argue that novel management actions will often be required to protect existing large old trees and ensure the recruitment of new cohorts of such trees. For example, fine-scale tree-level conservation such as buffering individual stems will be required in many environments such as in agricultural areas and urban environments. Landscape-level approaches like protecting places where large old trees are most likely to occur will be needed. However, this brings challenges associated with likely changes in tree distributions associated with climate change, because long-lived trees may presently exist in places unsuitable for the development of new cohorts of the same species. Appropriate future environmental domains for a species could exist in new locations where it has never previously occurred. The future distribution and persistence of large old trees may require controversial responses including assisted migration via seed or seedling establishment in new locales. However, the effectiveness of such approaches may be limited where key ecological features of large old trees (such as cavity presence) depend on other species such as termites, fungi and bacteria. Unless other species with similar ecological roles are present to fulfil these functions, these taxa might need to be moved concurrently with the target tree species.

Key words: defining large old trees, ecological functions, forest management, giant trees, hollow-bearing trees, snags, threatening processes, tree protection. 


\section{CONTENTS}

I. Introduction $\quad 5$

$\begin{array}{ll}\text { II. Approach } & 6\end{array}$

$\begin{array}{lll}\text { III. } & \text { Defining large old trees } & 7\end{array}$

IV. Key characteristics of large old trees 10

V. Key ecological roles of large old trees 13

VI. Cultural roles of large old trees for humans and animals 15

$\begin{array}{ll}\text { VII. Evolutionary processes and large old trees } & 17\end{array}$

VIII. Factors influencing the distribution and abundance of large old trees 21

IX. Population and other dynamics of large old trees 24

X. Threats and threatening processes $\quad 26$

(1) Drought 28

$\begin{array}{ll}\text { (2) Fire } & 29\end{array}$

(3) Pathogens and other pests 29

(4) Landscape fragmentation 30

(5) Climate change 31

XI. Multiple interacting threatening processes 33

XII. Conservation and management of large old trees 35

$\begin{array}{ll}\text { (1) Tree-level actions } & 37\end{array}$

(2) Landscape-level actions 39

(3) Management actions over appropriate temporal scales 40

XIII. Conclusions

Error! Bookmark not defined.

XIV. Acknowledgments 43

XV. References 43

XVI. Supporting information 


\section{INTRODUCTION}

“....old trees are the only terrestrial organisms to have lived through the entirety of the Industrial Age..." (Phillips, Buckley \& Tissue, 2008) (p. 1355)

Large old trees are among the biggest and most long-lived organisms on earth (Table 1). They have an important place in the human psyche and have many human cultural and aesthetic values (Blicharska \& Mikusinski, 2014) and symbolic significance (sensu Lester, 2010). Large old trees also play an array of ecological roles and have significant impacts on the distribution and abundance of many other entities ranging from water and nutrients to entire organisms including fungi, other plants (including other tree species), and numerous species of animals. Studies of large old trees provide novel perspectives on organism growth and development (Kartzinel, Trapnell \& Shefferson, 2013; Koch et al., 2015) that are not always congruent with studies of aging and development in animals (Issartel \& Coiffard, 2011; Penuelas, 2005) such as increased reproductive output with size (and therefore age) in some tree species (Thomas, 2011; Wenk \& Falster, 2015). The longevity, size, and patterns of spatial distribution of large old trees also can lead to new insights into evolutionary origins (Tng et al., 2012), long-term environmental changes (Phillips et al., 2008), and historical disturbance regimes (D'Amato \& Orwig, 2008).

However, the very attributes that confer evolutionary advantage for features such as extreme height make large old trees vulnerable to environmental stressors like drought (e.g. Rowland et al., 2015), increased frequency of lightning strikes associated with climate change (Romps et al., 2014), and human landscape transformation (Laurance et al., 2000). Indeed, we argue that large old trees are among the most imperiled organisms on earth and that their protection demands innovative approaches to management and monitoring over unprecedented time frames. Particular challenges arise from: (1) the rarity and limited spatial distribution of large old trees; (2) the requirement for prolonged periods of stability for 
growth and development coupled with their susceptibility to threats such as drought, dieback, and insect attack and relatively rare catastrophic events (such as severe fires and windstorms) that are very difficult to predict; (3) the array of potentially interacting threats that affect large old trees but that manifest in ecosystem-specific ways and thereby must be countered in ecosystem-specific ways; and (4) the difficulty of replacing large old trees and their numerous associated ecological and cultural roles once they have vanished from an ecosystem.

In this review, we provide new insights into the ecology, function, evolution and management of large old trees. We have attempted to achieve this through broad crossdisciplinary perspectives from literatures in plant physiology, growth and development, habitat value for fauna and flora, and conservation management. We also glean new perspectives by contrasting markedly different ecosystems spanning tropical, temperate and boreal forests to deserts, savannas, agro-ecological areas, and urban environments. By reviewing large old trees in such an array of ecosystems, our review transcends earlier perspectives on these keystone structures (sensu Tews et al., 2004) such as on protecting large old trees only within old-growth or primary forest.

\section{APPROACH}

We present here a narrative review of many aspects of the ecology, evolution, distribution and conservation of large old trees. We searched four major electronic databases [Web of Science (1945-present), Zoological Record Plus (1978-present), CAB Abstracts (1973-present) and SCOPUS (1960-present)] on 30 May 2015 using the following search terms: big trees, canopy trees, cavity using animals, cultural trees, drought, emergent trees, forest dynamics, forest fires, hollow-bearing trees, insect outbreaks, large trees, lianas, mega trees, old trees, snags, tree cavities, tree diseases, and tree mortality. We used different 
combinations of search terms based on the requirements or limitations of each database. No constraints on year of publication or language of publication were imposed on the database searches. Our search returned 1,563 articles. We then read their titles and abstracts and retained 742 papers relevant to our study of large old trees. All retained articles were read in full and additional works cited in the reference lists of those articles also were read. The full set of articles was then added to an extensive library of papers on large old trees that had been assembled by both authors over the past $30+$ years of research on the topic.

We elected not to conduct a formal systematic review or meta-analysis (sensu Lortie, 2014) of the literature for a range of reasons, but particularly because of the crossdisciplinary nature of our review and the limited number of empirical articles at the intersection of various key disciplines that related specifically to large old trees. Our narrative review subsequently spanned the following key topics in relation to large old trees: (1) definition; (2) key characteristics; (3) ecological roles; (4) cultural roles; (5) distribution and abundance; (6) evolutionary processes; (7) population and other dynamics; (8) processes threatening them; and (9) conservation and management.

\section{DEFINING LARGE OLD TREES}

Defining large old trees is challenging because they are an ecosystem-specific phenomenon; a large tree in an African or Australian savanna (Vanak et al., 2011; Williams et al., 1999) is far smaller than a large redwood in California (Sequoia sempervirens) (Sillett et al., 2015). Similarly, different tree species in the same ecosystem will obviously have varying maximum sizes and longevities. Definitions of large old trees can vary even among authors working in the same general ecosystems (Nilsson et al., 2002) and change according to scientific versus legal requirements (Lindenmayer et al., 2015). 
Rigorous ecosystem-specific approaches have been developed to distinguish large old trees from smaller trees based on morphology, such as their diameter, crown form, and loss of limbs. However, such classifications are confined to extensively studied environments like those dominated by Douglas fir (Pseudostuga menziesii) in eastern Washington, USA (van Pelt, 2008).

Large old trees can be characterized by extreme longevity, such as those beyond 5008000 years for individuals of some species (Owen, 2008). This includes some temperate rainforest and tropical rainforest trees (Chambers, Higuchi \& Schimel, 1998; Wood et al., 2010) and the giant gymnosperms of western North America (Sillett et al., 2015). However, we argue that the use of an age-specific criterion to define older trees (e.g. Nilsson et al., 2002) is problematic because age data are very challenging to acquire for an entire tree population, and for many individual tree species. Trees in seasonal environments often have distinctive growth rings but determining the ages of such trees requires them to be cored or cut, which is impractical in many instances (Sillett et al., 2015, Tsen et al., 2015) and culturally inappropriate in others (Blicharska \& Mikusinski, 2014). As an example, efforts to core one of the world's oldest trees resulted in it being destroyed (Eveleth, 2012). In individuals of some species, heart-rot and other factors can obscure growth rings and complicate dating (Banks, 1993; Waring \& O'Hara, 2006). There are also challenges in accurately aging very old trees in the tropics or aseasonal environments where growth rings are absent or less pronounced (Chambers et al., 1998; Martinez-Ramos \& Alvarez-Buylla, 1998). This can make it necessary to use methods such as radiocarbon dating (Chambers et al., 1998) or annual growth-increment and tree-diameter estimates from long-term demographic studies (Laurance et al., 2004a) to infer tree age.

Rather than relying on tree age, for the purposes of this review, we suggest that the definition of a large old tree should be based on its relative size (both diameter and height) and on a 
species-specific basis. Two key steps will therefore be important. First, it is important to establish the typical minimum diameter of reproductively mature (flowering and fruiting) individuals. Second, one can then define 'large' trees as being above a certain percentile, for example, the top $5 \%$ of all reproductive trees. However, we are acutely aware that the largest individuals of any particular tree species may not always be the oldest (Chambers et al., 1998; Cecile, Silva \& Anand, 2013). For example, fast-growing species such as some Populus spp. can attain large size relatively quickly but may not be old. Moreover, the oldest living trees are not always the tallest trees (Cecile et al., 2013; Moga et al., 2016) with strong evidence of tree height deterioration with prolonged age and canopy failure (Lindenmayer, Cunningham \& Donnelly, 1997).

Despite these caveats, we believe that for any particular species and ecosystem type it should be generally appropriate to define large and generally older trees. For example, using growth-ring analyses, tree diameter was strongly and generally linearly associated with tree age for ten hardwood and coniferous tree species in temperate North American forests [with diameter explaining an average of $78 \%$ (range: $47-92 \%$ ) of the variation in age for each species; Leak, 1985]. Similarly, tree diameter was strongly and generally linearly correlated with tree age for four species of montane coniferous and hardwood trees from Vietnam (Zuidema, Vlam \& Chien, 2011), six species of tropical hardwoods from Bolivia (Brienen \& Zuidema, 2006) and five species of tropical hardwoods from Cameroon (Groenendijk et al., 2014). Notably, such relationships become much weaker if age-diameter relationships are being assessed for an entire suite of species. For example, Chambers et al. (2001) found that tree diameter explained only $25 \%$ of the variation in estimated tree age (based on radiocarbon dating of tree cores for 44 trees in central Amazonia) but this was for 16 different tree species spanning eight tree families. 


\section{KEY CHARACTERISTICS OF LARGE OLD TREES}

Large old trees have an array of key attributes in addition to extreme age, height and girth, and which are not characteristic of large young trees or small young trees. These attributes include: (1) extensive buttressing (Nolke et al., 2015), which is most prevalent and extensively developed in large old tree cohorts (Cushman et al., 2014); (2) large and numerous cavities with extensive internal volume (Remm \& Lohmus, 2011) that are significantly more likely to develop in large old trees (Cockle, Martin \& Wesolowski, 2011; Fischer \& McClelland, 1983; Gibbons \& Lindenmayer, 2002); (3) large, well-developed crowns (Brokaw \& Lent, 1999; van Pelt \& Sillett, 2008); (4) large lateral branches (Franklin et al., 1981; Killey et al., 2010); (5) deeply fissured bark and/or extensive bark streamers (Lindenmayer et al., 2000; Pederson, 2010).

These attributes vary on a species-by-species basis as well as within species depending on disturbance history, local site conditions, growth form and other factors such as tree genotype (Jordan et al., 2000). For example, the large clumps of decorticating bark streamers that characterize large old mountain ash (Eucalyptus regnans) trees (the world's tallest angiosperm) (Lindenmayer et al., 2000) are not found on giant gymnosperms. Different species can exhibit inter-specific similarities in stature but marked divergence in growth dynamics. For example, mountain ash reaches top height more quickly but then also dies more quickly than do giant gymnosperms such as California redwoods (Sillett et al., 2010). Many species of large old trees continue to add diameter with age (Stephenson et al., 2014) but there appear to be limits to maximum height, likely as a result of hydraulic pressure constraints curtailing the movement of water to the canopy (Phillips et al., 2008; Sillett et al., 2010; Koch et al., 2015). Rates of tree diameter growth tend to be much lower in older (>200-400 year old) trees than in younger individuals (Ashton, 1975; Chambers et al., 1998). 
Within species, growth forms can be profoundly influenced by whether a given individual grew in a dense stand or in an open environment such as an agricultural field, with the former tending to have tall branches and the latter branching at all vertical levels. In addition, the development of some of the key characteristics of large old trees may be strongly influenced by periodic events such as fires or windstorms (Inions, Tanton \& Davey, 1989). This means their development may not be linearly related to time.

Many of the key attributes of large old trees exhibit spatially variable distribution patterns. For example, dead standing trees have larger average diameters in temperate and boreal forests than in tropical and sub-tropical forests (Gibbs, Hunter \& Melvin, 1993). A global study revealed that the prevalence of large old trees with cavities varies with rainfall patterns and other factors such as the abundance of primary cavity nesters (Remm \& Lohmus, 2011), although this does not hold on continents like Australia where groups such as woodpeckers are absent (Gibbons \& Lindenmayer, 2002). Links between cavity prevalence and rainfall patterns may be allied with the fact that precipitation also influences the abundance of large old trees (Slik et al., 2013) (see Section VIII); links between tree size and the probability of cavity development are well established empirically (Lindenmayer et al., 1993; Remm \& Lohmus, 2011).

It is ironic in an evolutionary context that some of the key attributes of large old trees also can contribute to their demise. For example, extreme height can trigger hydraulic deterioration and greater levels of mortality relative to smaller trees (Rowland et al., 2015). The presence of cavities which often characterize large old trees (Cockle et al., 2011) can weaken a stem and increase its risk of failure and collapse. Similarly, the long bark streamers of giant eucalypts (Fig. 1) can readily carry fire to the canopy with trees subsequently being killed by a crown-scorching conflagration. The reasons for the development of, and presumably continued selection for, many such features remain unresolved. However, recent 
work from Central America suggests that large old trees benefit from the extra nutrients brought by animals attracted to key features like cavities (Voight, Borissov \& Kelm, 2015).

Changes in characteristics of large old trees over time also can make them susceptible to direct human removal. For example, increasing rot and/or the presence of cavities in ageing trees can result in them being perceived as being diseased or a human safety or fire risk. In New Zealand, the development of cavities in large old trees means they are sometimes targeted for removal because they are occupied by pest species such as the common brushtail possum (Trichosurus vulpecula) which are, in turn, carriers of bovine tuberculosis that can be spread to domestic livestock (Fairweather, Brockie \& Ward, 1986).

There are substantial challenges in studying certain attributes of large old trees such as features that cannot be accurately quantified using ground-based methods. The presence and attributes of cavities is an example (Cockle et al., 2011). Destructive tree dissection to explore internal cavity dimensions (Mackowski, 1987) is inappropriate in very large, rare or ecologically and culturally important specimens. Destructive sampling also can damage particular features and hence preclude their effective study (e.g. the architecture of buttresses, crowns or large lateral branches) (Nolke et al., 2015; Sillett et al., 2015). Time-consuming methods such as climbing trees to complete above-ground measurements may be required to meet some of these challenges, although emerging technologies such as laser scanning and light detection and ranging (LIDAR) can make useful contributions in some contexts (Thomas et al., 2013; Nolke et al., 2015) and have helped to reveal huge individuals of existing tree species (Yard, 2013).

In summary, large old trees support a wide range of key attributes that are either poorly developed or absent from smaller, younger trees. Many of these attributes are relatively well documented such as tree height, diameter and the presence of cavities. Others are not and remain poorly studied and understood. The canopies of large old trees have often been 
considered as new frontiers for the discovery of huge numbers of species (Ozanne et al., 2003). But there are other likely highly species-rich environments associated with some species of large old trees that remain almost entirely unexplored. The extensive decorticating bark microhabitats of Australian eucalypts is one such example (Fig. 1).

\section{KEY ECOLOGICAL ROLES OF LARGE OLD TREES}

Large old trees play a huge array of key ecological and other roles (Table S1). These include having large influences on hydrological regimes, nutrient cycles and numerous critical ecosystem processes. For example, large old trees are vital in facilitating ecosystems recovery after fire (Lutz, van Wagtendonk \& Franklin, 2009) and overgrazing (Fischer et al., 2009), developing and maintaining nutrient and biodiversity hotspots in deserts (Dean, Milton \& Jeltsch, 1999) and forests (Jayasekara et al., 2007; Voight et al., 2015), and facilitating connectivity via promoting animal movement under climate change (Manning et $a l ., 2009)$. Large old trees also play critical roles in carbon storage and therefore in maintaining forest carbon stocks (Chen \& Luo, 2015; Slik et al., 2013). Indeed, large old trees are a small proportion of the number of stems in a stand but large contributor to carbon biomass (Clark \& Clark, 1996; Keith, Mackey \& Lindenmayer, 2009). In some forest types, the largest and oldest trees continue to accumulate large amounts of biomass (Stephenson et $a l ., 2014)$, including right up to the time of apical crown collapse, even though these trees are often also the most decayed individuals (Koch et al., 2015).

Large old trees also strongly influence the spatial and temporal distribution and abundance of individuals of the same species and populations of numerous other plant (Punchi-Manage et al., 2015) and animal species and profoundly influence the structure of entire communities of organisms (Martin, Aitken \& Wiebe, 2004; Stahlheber et al., 2015). The importance of large old trees as habitat for animals and other plants is so considerable 
that they can act as 'biodiversity hotspots' by supporting far more species than elsewhere in the surrounding landscape (Dean et al., 1999). Indeed, some species almost exclusively use large old trees (Le Roux et al., 2015). For some animal species, dependencies are so strong that the occurrence of large old trees acts as a robust, cost-effective surrogate for animal presence and abundance (Lindenmayer et al., 2014). Some regions such as South Africa and Australia have disproportionate numbers of species closely associated with large old tree attributes (e.g. Roberts, 1971). For example, $42 \%$ of the mammal and $28 \%$ of the reptile fauna in south-eastern Australia depends on cavities in large old trees (Gibbons \& Lindenmayer, 2002).

The ecological roles of large old trees extend well beyond the immediate zone of the individual stem and influence ecological processes and spatial patterns of biodiversity occurrence and abundance at multiple spatial scales, including across landscapes (Table S1). Indeed, some species occur in a given area only because of the presence of large old trees, even in highly modified environments such as those dominated by exotic tree plantations (Kavanagh \& Turner, 1994) and urban settlements (Carpaneto et al., 2010).

Large old trees also have a significant temporal footprint, playing many key ecological roles that extend well beyond their often prolonged lifespans (Stahlheber et al., 2015). For example, the animal-habitat roles of large old trees can persist for many decades and even centuries after trees have died (Rose et al., 2001). Large old trees also act as critical germination substrates for other plant species for prolonged periods after their death (McKenney \& Kirkpatrick, 1999) (reviewed by Harmon et al., 1986). The presence of large dead trees in young forests regenerating after disturbance can promote the persistence of many animal and plant species that might otherwise be lost from such areas, facilitating temporal continuity in long-term species occurrence (reviewed by Franklin et al., 2000). Similarly, the significant carbon-storage role of large old trees (Sillett et al., 2010; 
Stephenson et al., 2014) can be retained even following high-severity stand-replacing disturbances through the long-term maintenance of carbon in dead stems (Keith et al., 2014a). Changes in soil nutrients associated with a shift in carbon from pools in large old trees to the soil for prolonged periods after tree death are also well documented (Harmon et al., 1986).

Large old trees have so many key ecological roles that it is challenging even to list them (see Table S1). Many are well known, but others remain poorly understood such as the relationships among cavity use by animals, nutrient transfer, soil fertility and tree growth (Voight et al., 2015). Many of these key ecological roles interact, such as the interrelationships among the occurrence of fauna, the dispersal of propagules, tree growth, and carbon storage (Bello et al., 2015). For instance, chronic overhunting of tropical mammals and birds that disperse large seeds (which are associated with large, densely wooded, shadetolerant tree species that store large amounts of carbon) is expected to lead to substantial (212\%) carbon losses in Neotropical, African and South Asian forest, where such large-seeded species are especially prevalent (Osuri et al., 2016). However, very few studies have examined such important interactions. More are urgently needed both to better quantify the roles of large old trees and changes in ecosystem and other functions when populations of large old trees are depleted or lost entirely.

\section{CULTURAL ROLES OF LARGE OLD TREES FOR HUMANS AND ANIMALS}

Humans have strong cultural connections with large old trees, both in natural areas and urban environments. They often feature in paintings, oral histories and iconic books like those by Tolkein and Enid Blyton (the Ents and the Magic Faraway tree) as well as in recent films, such as Avatar. The long lifespans of trees is illustrated by historical paintings of large old trees that still exist today, albeit where the surrounding landscape has often changed 
profoundly over centuries (Fig. 2). Large old trees are also prominent in pagan rituals and animist beliefs as well as being part of many religions, such as as sacred sites for some communities and faiths (e.g. the locations of burial sites of saints) (Blicharska \& Mikusinski, 2014). For example, large old bayan (Ficus benghalensis) trees are holy sites for Hindus in India and elsewhere in Asia (such as the Indonesian island of Bali) and are visited by tens of millions of people annually.

Human attachment to such 'charismatic' organisms has meant that many individual large old trees have been given unique names such as Centurion, Methuselah, and General Sherman - unlike virtually any other plants and the vast majority of animals including charismatic vertebrate 'mega-fauna'.

Large old trees can have significant socio-economic values. For example, the California redwoods are a major tourism asset in western North America, attracting more than 330,000 visitors annually and generating more than \$US20 m annually in non-local visitor spending (http://www.nps.gov/red/learn/news/national-park-service-releases). Elsewhere, such as south-western Australia and southern Tasmania, areas supporting large old trees have formed the basis of major tourism ventures that attract numerous visitors each year and have rejuvenated the economy of entire regions (e.g. Winfield \& Svenson, 2009).

Perversely, strong human cultural connection to large old trees and their economic value also can have fatal consequences for trees. This can occur through, for example, excessive visitation leading to soil compaction and the spread of pathogens. Such trees also can be targets for vandalism, such as by those opposed to conservation activities. In some cases, the location of large old trees is kept secret to protect them (e.g. in the case of the 'living fossil' wollemi pine Wollemia nobilis in south-eastern Australia).

Some animals have strong apparent 'cultural' connections to large old trees and may even persist in particular locations where these trees used to occur but now no longer exist. 
The eclectus parrot (Eclectus roratus) of Australia is an example; this species may forego breeding and remain for prolonged periods in the vicinity of a collapsed nest tree ( $R$. Heinsohn, unpublished data). Similar observations have been made for the Lumholtz's treekangaroo (Dendrolagus lumholtzi) in north Queensland, where individuals stayed with their trees even after they had been clear-felled by chainsaw and bulldozer (Newell, 1999). As in human societies, animal cultural connections to large old trees also can be 'unlearned'. For example, the establishment of nest boxes in parts of the UK resulted in populations of the tawny owl (Strix aluco) changing nest-selection preferences away from large old trees (Newton, 1998). Other bird species such as the great tit (Parus major) are known to exhibit similar patterns of 'behavioural unlearning' from natural cavities to nest boxes (Drent, 1984).

In summary, humans and animals alike have strong cultural connections to large old trees that can take a range of different forms. In the case of humans, it will be interesting to determine if the trend for increasing urbanization and disconnection from nature (Louv, 2005) translates into a diminished appreciation of large old trees or if appreciation of them will be maintained via books, films and other media. We note, however, that a group of senior foresters in south-eastern Australia failed to recognize stands of large old mountain ash trees despite younger stands of this same species being the primary wood-production tree cut extensively elsewhere under their direction!

\section{EVOLUTIONARY PROCESSES AND LARGE OLD TREES}

In terms of their life history, large old trees are among the more evolutionarily distinctive organisms on the planet. Their extreme longevity and long generation times create both opportunities and hazards in ecological and evolutionary terms. Large size must have selective advantages or it would not have evolved in the first place. Key factors that likely favour tall trees are their capacity to dominate nearby plants in competition for light (by 
overtopping them and via lateral crown expansion), soil nutrients, and water. Large trees may also be less sensitive to physical damage, such as might occur via tree- or branch-fall from nearby trees (Thomas et al., 2013). Given their extensive and often-deep root systems (many tropical rainforest trees tend to be shallow-rooted because most nutrients come from litterfall decomposing on the forest floor), taller trees might also be better adapted than are smaller species to low-nutrient environments (Poorter et al., 2008). However, the largest trees on continents like Australia are confined to areas with the most fertile soils. Tng et al. (2012) hypothesized that giant eucalypts in Australia evolved in environments subject to highseverity fire necessary for germination but also characterized by conditions promoting rapid growth without a need for extreme longevity. Finally, because large old trees can provide food and shelter for a large array of animal species and substrates for the growth of many other plant species (Table S1), they might function as 'nutrient traps' - gaining critical nutrients such as nitrogen and phosphorus from the waste of animals that feed on, nest in, or den inside the tree (Dean et al., 1999) or benefitting from boosted site productivity generated by nitrogen-fixing plants living on their trunks and lateral branches (Lindo \& Whiteley, 2011). Recent work from Central America has revealed that faeces from bats using cavities of large rainforest trees add extra nutrients that are taken up from the soil by the mesh of fine roots of these trees (Voight et al., 2015).

The extreme longevity and size of some tree species result in important trade-offs in growth, metabolism and reproduction (Penuelas, 2005; Thomas, 2011). For example, whereas the fraction of a plant's metabolism dedicated to reproduction varies markedly among species (Wenk \& Falster, 2015), reproductive allocation in many long-lived tree species does not asymptote but rather continues to increase throughout their lives (Hirayama et al., 2008). In another example, Issartel \& Coiffard (2011) hypothesized that extreme longevity can be explained by particularly low rates of metabolism in the stems of large old trees, which 
contrasts with much higher rates of energy allocation and senescence in the tree's leaves. We further hypothesize that such trade-offs through the low metabolic rate of stems may ultimately set an upper limit on tree longevity.

A long lifespan provides large trees with many opportunities for reproduction (Thomas, 2011). This 'storage effect' (Chesson \& Warner, 1981) means that adults can withstand long periods of unfavourable conditions for seed production or juvenile recruitment. For instance, some large tree species, such as Douglas fir, rose gum, and mountain ash rely on rare, standreplacing fires to eliminate competitors and/or provide fertile ash beds for seedling recruitment (Franklin et al., 2002; Smith et al., 2013).

Extreme size and longevity also means that trees can attain a size and canopy stature that allows them to produce massive seed crops. Reproductive allocation generally increases with tree size (Thomas, 2011), and the biggest trees can thereby overwhelm recruitment at local and landscape scales. For instance, genetic fingerprinting has revealed that a few large remnant trees produced abundant seedlings that dominated recruitment across a fragmented landscape in Costa Rica (Nason \& Hamrick, 1997). Because seed and fruit production is energetically expensive (Wenk \& Falster, 2015), we hypothesize that tree fertility will be generally proportional to the volume of photosynthesizing foliage, especially that in the upper canopy and emergent layers where photosynthetically active radiation is most abundant.

Extreme size and longevity also bring evolutionary and ecological risks. Reproduction in large trees is often strongly dominated by a few individuals (Nason \& Hamrick, 1997; Aldrich \& Hamrick, 1998; Dick et al., 2008), potentially translating into a small effective population size $\left(N_{\mathrm{e}}\right)$. Species that have small $N_{\mathrm{e}}$ could be vulnerable to factors that increase mortality of the largest, most reproductively active individuals. For example, elasticity analyses with minimum viable population models demonstrate the critical role of adult survival in many long-lived plant and animal species (Bell, Bowles \& McEachern, 2003). In 
this sense, clearcut logging systems that fail to retain large trees, or selective logging regimes that target the largest individuals, could have major negative impacts on genetic diversity (York, 2015).

The small effective population sizes of large trees mean that they may be particularly vulnerable to genetic bottlenecks. The impacts of such bottlenecks on genetic diversity are not just a function of bottleneck 'size' (i.e. population size), but also bottleneck 'width' (i.e. the number of generations in which the species experiences a small population size; Bouzat, 2010). Species that recover rapidly from population collapses can actually retain much of their genetic variation (Bouzat, 2010). This means that efforts to propagate and breed longlived tree species that have become rare could play an important role in their genetic management. Such efforts may become essential because the forces that are increasing largetree mortality (e.g. habitat loss and fragmentation, logging regimes, increasing droughts, novel pathogens and enemies, altered fire regimes; see Section X) are often chronic and longterm in nature. For these reasons it may be very difficult for large trees to recover and maintain genetic diversity without active interventions.

We suggest that large old trees offer a unique opportunity to study genetic and epigenetic changes in individuals over long time spans (Bräutigan et al., 2013). In large old trees, the genotype may vary between old tissues (adapted to earlier environmental conditions) and new tissues (that have accumulated random genetic changes over time, or that have accrued mutations because of environmental impacts). Conversely, new tissues may still have the same genotype, but a different phenotype and this epigenetic change may also alter tissue functions (Bräutigan et al., 2013).

Another disadvantage of extreme adult longevity is that the climatic niches (and regeneration niches; sensu Bell, 1999) of older individuals may differ from current conditions (Smith et al., 2016). This could create inherent lag-effects that are destabilizing for 
population persistence, especially when climatic conditions are changing rapidly. The giant Australian flowering plant, mountain ash, is a useful example of this problem. Bioclimatic modelling has demonstrated that the species occupies a relatively narrow set of climatic conditions with other tree species dominating adjacent environmental domains (Lindenmayer, Mackey \& Nix, 1996). Simulations of projected future climatic conditions suggest that areas supporting suitable bioclimatic conditions for mountain ash will be rapidly depleted by 2050 (Lindenmayer et al., 1991b). Therefore, areas currently supporting the species will likely be unsuitable for germination in the future. Contemporary and future climatic changes could create major problems for the persistence of some large tree species. Species that have large propagules, typically dispersed by larger animals, gravity or water, may be limited in their capacity to disperse latitudinally or elevationally as climatic conditions change.

\section{FACTORS INFLUENCING THE DISTRIBUTION AND ABUNDANCE OF}

\section{LARGE OLD TREES}

The distribution and abundance of large old trees can be influenced by combinations of multiple factors acting over multiple spatial and temporal scales (Vanak et al., 2011; Ikin et al., 2015; Lindenmayer et al., 2016, Moga et al., 2016). Key drivers at large spatial scales include rainfall, temperature and soil fertility (Slik et al., 2013). However, in a cross-taxon analysis, Tng et al. (2012) showed that species characterized by heights exceeding $70 \mathrm{~m}$ occupied a very broad environmental envelope (based on precipitation and evapotranspiration) that also contained many vegetation types that did not support such tall trees. We suggest that this indicates other factors play important roles in the evolution and development of large old trees. Individual species traits are correlated with large old tree abundance; for example, the large old trees that occur at the highest population densities in 
tropical forests, such as the dipterocarps in Southeast Asia, are wind-dispersed tree species with high wood density (Slik et al., 2013).

At landscape and local scales, factors such as slope, aspect, proximity to watercourses, topographic wetness, soil depth, and the prevalence of herbivores can be important determinants of the occurrence of large old trees (Lindenmayer et al., 1991a; Pederson, 2010; Vanak et al., 2011; Thomas et al., 2013; Ikin et al., 2015). In some cases, places naturally supporting large old trees will be those characterized by optimal conditions for tree growth (Jones, 1997), although these same highly productive places are also those often targeted for activities like logging.

The distribution and abundance of large old trees is also driven by events such as natural disturbances. Recurrent fire can reduce or eliminate populations of large old trees from particular areas (Barlow et al., 2003; Lindenmayer et al., 2012a) as can widespread insect attack (Kashian, Jackson \& Lyons, 2011; Popkin, 2015) and dieback from pathogens or toxins such as acid rain (Palik et al., 2011). Conversely, floods, high-severity fire or periodic relief from high-intensity ungulate grazing can trigger regeneration cohorts that lead to recruitment pulses of trees (George, Walker \& Lewis, 2005; Moe et al., 2009; Smith et al., 2013).

Human management is also a key driver of the distribution and abundance of large old trees; logging, clearing, prescribed fire and other activities such as prolonged livestock grazing strongly influence where large old trees are found (Nilsson et al., 2006; Kauppi et al., 2015; Moga et al., 2016). The economic value of land also can have substantial impacts on the occurrence and abundance of large old trees. For example, large old trees are likely to be absent or scare in economically valuable agricultural areas and commercial forests where land is used for commodity production. 
Significant cultural reasons (beyond factors associated with natural resource management and human disturbance) can also underpin the occurrence of large old trees. For example, some very large trees occur in particular places because they have been preserved for religious or other cultural reasons (Blicharska \& Mikusinski, 2014). For example, the thousands of Church Forests of Ethiopia (retained because the Eastern Orthodox religion believes their churches should be 'havens for God's creatures') are some of the most important forest refugia in the nation (Wassie, Sterck \& Bongers, 2010).

Quantifying the factors influencing large old tree distribution and abundance is critical for management such as identifying refugia where such trees have the greatest long-term chances of persistence both now and in the future (see Section XII). Yet at the same time, we suggest that at least four inter-related problems can complicate analyses of large old tree distribution and pose non-trivial challenges for widely applied methods such as species distribution modelling (sensu Elith \& Leathwick, 2009). First, different environmental factors can influence trees at different stages of their life cycle (Smith et al., 2016). The large old tree growth stage may occupy only a small subset of the overall climatic and environmental envelope for a given tree species (Mackey et al., 2002). Second, the extent of past and current land uses means that many trees have been removed from large areas of their former distribution (Crowther et al., 2015) and in some cases we may know little about their past distribution. This may mean that remaining large old trees are now confined to areas where past logging or land clearing did not occur and these places may not be representative of locations potentially suitable for such trees. Third, large old tree distribution and abundance can be affected by rare and episodic events such fires or floods, the timing of which are notoriously difficult to predict. Finally, some very long-lived tree species may have germinated under environmental conditions that were markedly different from those that 
currently exist at that location. Hence, it may be difficult to assign the current distribution of a given species of large old tree to contemporary environmental conditions.

Despite the challenges in accurately modelling and predicting the distribution and relative abundance of large old trees, improved understanding of where they occur and why they occur there is critical for better spatial and temporal targeting of management actions (Ikin et al., 2015). We suggest that increasing use of technologies such as remote-sensing LIDAR can help to detect and map emergent and sub-canopy large old trees better, particularly for forest environments (e.g. Thomas et al., 2013). In addition, there will be value in developing more powerful species distribution models (sensu Elith \& Leathwick, 2009) that help quantify the subset of a tree species' potential niche where large old trees are more likely to occur (e.g. Smith et al., 2012).

\section{POPULATION AND OTHER DYNAMICS OF LARGE OLD TREES}

Adult mortality and recruitment are two key life-cycle components that strongly affect the dynamics of populations of large old trees. Adult mortality, in particular, has a critical impact on all long-lived organisms (Fritz, Bininda-Emonds \& Purvis, 2009), including large old trees (Gibbons et al., 2008b). In some ecosystems, however, a paucity of natural regeneration is also threatening the development of new cohorts of trees to replace existing populations of rapidly senescing large old trees (Weinberg et al., 2011; Manning et al., 2013). Such trends are evident in many forests in India, Australia and South Africa where the introduced Neotropical shrub Lantana camara grows so densely that natural tree regeneration is impossible (Bhagwat et al. 2012).

There is considerable temporal and spatial heterogeneity in mortality patterns of large old trees and this may give rise to different estimates of mortality, even for the same broad ecosystem [for instance, compare van Mantgem et al. (2009) with Acker et al. (2015)]. Such 
variation can be complicated by the fact that mortality is an outcome of: (1) chronic (background, non-catastrophic) processes (van Mantgem et al., 2009) with tree death influenced by many different factors (Stephenson et al., 2011), such as competition and age (Richardson et al., 2009) but also linked to other related attributes like tree height (Thomas et al., 2013) and diameter (Lindenmayer et al., 1990); and, (2) episodic event-based processes resulting from catastrophes such as fires (Lindenmayer et al., 2012a), droughts (Nepstad et al., 2007; Rowland et al., 2015), windstorms (Webb, 1988; Platt, Doren \& Armentano, 2000), insect attack (Shore, Brooks \& Stone, 2003) and damage by large herbivores (Morrison, Holdo \& Anderson, 2016).

In some ecosystems, such as tropical forests of Central America and temperate forests in New Zealand and western North America, mortality rates of large old trees appear to have remained relatively stable (Richardson et al., 2009; Thomas et al., 2013; Acker et al., 2015). Conversely, populations of large old trees are declining rapidly in other ecosystems. These include: (1) forests in western North America (Lutz et al., 2009), south-eastern USA (Jones, 1997), and south-eastern Australia (Lindenmayer et al., 2012a); (2) agricultural areas in parts of Europe (Gibbons et al., 2008b) and southern Australia (Maron \& Fitzsimons, 2007; Fischer et al., 2010b); (3) savannas in Africa and Australia (Vanak et al., 2011; Williams et al., 1999); and (4) urban environments in Europe (Carpaneto et al., 2010), among others. A wide range of factors underpin these declines including land clearing, fire, logging, removal for human safety in urban streetscapes, and abundant exotic or native herbivore populations.

Large old tree populations are increasing in other ecosystems such as boreal and hemiboreal ecosystems in Finland and other forested ecosystems in eastern and western USA (Kauppi et al., 2015) as well as some tropical ecosystems in Africa and South America (Fashing et al., 2004; Lewis et al., 2009a). Land-use changes, particularly reduced logging, agricultural land abandonment and/or declining incidence of fire, appear to be drivers of 
increases in some large old tree populations (Kauppi et al., 2015). These positive trends may reflect recovery from very low baseline population sizes (such as in the north-eastern USA; D'Amato, Orwig \& Foster, 2009). Nevertheless, we argue that positive increases in some ecosystems indicate that it is wrong to describe populations of large old trees as the 'living dead' (Janzen, 1986), particularly given prolonged adult longevity, high levels of seed production in some very large old trees (Clark \& Clark, 1996; Thomas, 2011) and the potential for targeted management to limit mortality, promote recruitment or both (see Section XII).

We suggest that significantly more long-term data sets are required to better quantify key components of the temporal dynamics of large old trees, including the factors affecting rates of mortality. Statistical methods such as zero-inflated Poisson regression (Welsh et al., 1996) and match-case control borrowed from other fields like product manufacturing and medicine can be useful in analysing temporal dynamics of large old trees. Such approaches could help researchers to predict the responses of individual trees better to rare and/or catastrophic events including the risks of premature death and collapse. A related further challenge is a need to define 'baseline' values for the density of large old trees in 'natural ecosystems' as a benchmarking exercise and to create abundance and distribution targets for conservation and restoration programs (Nilsson et al., 2006). However, many environments have a prolonged history of human use and widespread and consistent tree removal (Crowther et al., 2015). This can make it difficult to develop benchmarks for large old trees, such as for most European forests (Nilsson et al., 2002) and for temperate woodland ecosystems in agricultural Australia (Gibbons et al., 2010).

\section{THREATS AND THREATENING PROCESSES}


Large old trees are susceptible to a wide range of interacting threatening processes. These include human land uses such as land clearing (deforestation), the establishment of human infrastructure (such as roads and houses; Forman, 2014), selective and clear-cut logging (Lindenmayer et al., 2016; Schiermeier, 2016), agriculture, and grazing. It has recently been estimated that more than 15 billion trees are cut annually (Crowther et al., 2015), thereby significantly reducing global populations of many tree species, including large tree species. Other aspects of human land use can have significant negative impacts on populations of large old trees. For example, some have argued that because large old trees grow more slowly than younger-aged individuals, they should be cut down and replaced with young regenerating stands that are believed to fix more carbon more quickly. However, recent research suggests that large old trees continue to accumulate large amounts of biomass throughout their lives (Stephenson et al., 2014; Koch et al., 2015). Actions to protect such trees can store significantly greater amounts of carbon and lead to substantially less carbon emissions than logging and regenerating forest (Keith et al., 2014b, 2015; MacIntosh, Keith \& Lindenmayer, 2015). Social and institutional instability also can threaten populations of large old trees. For example, institutional and political change in Poland is opening longreserved forests for logging that will trigger the loss of huge numbers of large old trees (Schiermeier, 2016).

Beyond direct human land-use effects, other factors threaten populations of large old trees including drought, fire, windstorms, populations of large native herbivores, and invasive species including pathogens (Table S2). Some of these factors interact (Vanak et al., 2011) and their impacts also can affect different stages of the life cycle of large old trees in different ways. For example, very old trees containing large amounts of dead wood can be destroyed by fire (Lindenmayer et al., 2012a); yet fire also can be essential for accelerating the 
development of key attributes like cavities (Inions et al., 1989) and stimulating the germination of new cohorts of fire-adapted trees (Franklin et al., 2002; Smith et al., 2013).

Just as large old trees can be susceptible to disturbances, they also can contribute to disturbances, such as promoting spatial expansion of canopy gaps in forests (Young \& Hubbell, 1991) and acting as a source of sparks that spread fire across landscapes (Crowe, Paxton \& Tyers, 1984) (Fig. 3).

\section{(1) Drought}

Many species of large old trees are surprisingly susceptible to droughts (Leighton \& Wirawan, 1986; Condit, Hubbell \& Foster, 1995; Nepstad et al., 2007; Allen et al., 2010; Anderegg, Kane \& Anderegg, 2013; Rowland et al., 2015). Across a wide range of ecosystems, trees are evidently being pushed by competition to maximize their photosynthetic and growth rates, which in turn makes them live 'near the edge' in terms of their vulnerability to droughts (Choat et al., 2012). This raises an important, yet presently unresolved, question in that if many tree species occur at the margins of their physiological drought tolerance (Choat et al., 2012), how is it possible that large old trees persist in many ecosystems? Available evidence suggests that hydraulic failure (an inability to transport enough water up to the foliage of tall trees, often because of cavitation in the water-carrying xylem vessels) rather than gradual carbon starvation (which could result because trees lack enough water to photosynthesize sufficiently) is the principal cause of death in droughtstressed trees (Rowland et al., 2015). Notably, in addition to the marked vulnerability of large trees, different tree taxa show strongly varying sensitivities to drought. In the Amazon, for instance, trees in the genus Eschweilera are extremely drought-sensitive whereas those in the genus Licania are surprisingly resistant (Meir et al., 2015). This suggests that increasing 
droughts could not only kill many large trees but also drive fundamental changes in forest composition.

\section{(2) Fire}

Wildfires and prescribed burning can have significant negative impacts on populations of large old trees, not only in forests but also in agricultural landscapes (Bluff, 2016; M. Crane, D.B. Lindenmayer, R.B. Cunningham, et al., 2016). Conversely, many species of large old trees depend on fire for regeneration of seedlings (Franklin et al., 2002; Smith et al., 2016). For these species, the fire regime (sensu Keeley, 2009), including the frequency, severity, and fire interval, has critical effects on populations of large old trees. Given the prolonged time to reproduction in many species of large old trees (Thomas, 2011), frequent fire may not only remove cohorts of large old trees and their juveniles but eliminate a given species from a fire-prone area (Lindenmayer et al., 2011). Like many other threatening processes, fire can interact with other factors such as habitat fragmentation and logging (Cochrane \& Laurance, 2008), fungal attack and populations of large herbivores (such as elephants) (Vanak et al., 2011) to influence populations of large old trees.

\section{(3) Pathogens and other pests}

An alarming reality for large old trees is that they will evolve far more slowly than most of their enemies, such as pathogenic microbes, fungi, herbivorous or wood-boring insects, and vertebrate folivores. A classic example is the collapse of populations of the American chestnut (Castanea dentata) throughout the eastern USA as a result of the introduction of chestnut blight (Cryphonectria parasitica) from Asia. The largest (and culturally significant) kauri (Agathis australis) trees in New Zealand are vulnerable to the effects of an introduced fungus-like pathogen (Phytophthora sp.) discovered in that country 
only a decade ago and for which there is presently no known effective treatment (Kauri Dieback, 2012).

The negative impacts of invasive species is likely to be an increasingly important factor given the explosive rate at which foreign species are being introduced into ecosystems (Daszak, Cunningham \& Hyatt, 2000; van Kleunen et al., 2015). Introduced enemies often have dramatic impacts on immunologically suppressed or otherwise naïve host populations (Daszak et al., 2000). Pathogens that cause large-scale host mortality might eventually experience an evolution of 'intermediate virulence' (Anderson \& May, 1982) but a key question is whether such changes might occur too late for collapsing populations of large trees, which could be impacted not just by new enemies but also by a host of other threatening processes.

Some introduced enemies can significantly alter natural disturbance regimes and in turn significantly affect populations of large old trees. For example, in northern Australian savannas, gamba grass (Andropogon gayanus), which grows up to $5 \mathrm{~m}$ tall, is substantially increasing fire intensity (Setterfield et al., 2010; Bowman et al., 2014). Even for sclerophyllous trees adapted to frequent fires, such intense fires are proving fatal. The spread of gamba grass has even prompted one researcher to suggest that elephants be introduced to Australia in an effort to control it (Bowman, 2012) (a suggestion that, notably, drew criticism from many quarters).

\section{(4) Landscape fragmentation}

The evolutionary pressures that select for tall trees and provide competitive advantages (see Section VII; Thomas et al., 2013) may mean that such species are maladapted to human disturbances such as habitat fragmentation. Large individuals, which become thicker and less flexible as they grow, can be especially vulnerable to wind damage in fragmented landscapes, 
where wind shear and turbulence can be markedly increased (Laurance et al., 2000). Clearing and forestry activities can lead to increased lightning-initiated fire in some regions (Krawchuk \& Cumming, 2009) and because of their height, large trees may be at particular risk of lightning strike (Magnuson, Lima \& de Lima, 1996). Because large individuals are often near their physiological limits in terms of transporting water to their uppermost foliage (Choat et al., 2012), they can be susceptible to increased desiccation stress that results from large vapour-pressure deficits in fragmented landscapes. This occurs because the vegetation surrounding fragments, such as pastures or crops, produces much less evapotranspiration and thus is drier and hotter than forests (Kapos, 1989). These effects can occur over surprisingly large spatial scales (up to several kilometres from clearings) because of large-scale canopy desiccation (Briant, Gond \& Laurance, 2010), possibly resulting from induced vegetationbreeze effects (Cochrane \& Laurance, 2008). Creation of a new forest edge (which is structurally open and thereby highly permeable to microclimatic stresses) often results in a sharp die-off of desiccation-sensitive trees in the first few months following edge creation (Laurance et al., 2002). Fragmentation also can favour certain competitors and structural parasites of large old trees, such as climbing vines and lianas (Laurance et al., 2001, 2014).

\section{(5) Climate change}

Increased tree cover and particularly increased populations of large old trees (which store a disproportionately large amount of carbon) are critical for tackling dangerous climate change. However, the effects of climate change on large old trees remain contentious and uncertain. Some authors suggest that climate change and associated increases in greenhousegas concentrations could negatively affect large old trees (Anderegg et al., 2013; van Mantgem et al., 2009) by inducing droughts that could kill big trees through increased vapour-pressure deficits, embolisms in conducting tissues (Pfautsch et al., 2016) or lowered 
groundwater tables (Slik et al., 2013), by raising metabolic rates and possibly suppressing photosynthesis of heat-stressed trees, reducing the amount of energy available for tree growth (Clark et al., 2003), by increasing rates of tree mortality and turnover as a result of elevated tree growth and competition caused by $\mathrm{CO}_{2}$ fertilization or increased insolation (Lewis, Malhi \& Phillips, 2004; Phillips \& Gentry, 1994; Laurance et al., 2004b), by favouring climbing vines that are intense competitors and structural parasites of trees (Laurance et al., 2013), by increasing pathogen prevalence and virulence via increased temperatures and humidity (Daszak et al., 2000), and by potentially increasing lightning strikes (Romps et al., 2014), to which tall trees may be especially vulnerable (Magnuson et al., 1996). Conversely, other authors argue that climatic and atmospheric changes might benefit large trees by leading to $\mathrm{CO}_{2}$ fertilization, which can increase tree growth rates (Phillips et al., 1998; Lewis et al., 2009b) and possibly create competitive advantages for large trees, which appear to respond more positively to elevated $\mathrm{CO}_{2}$ than do smaller trees because they receive abundant sunlight in the upper forest strata (Laurance et al., 2004b), and by increasing the water-use efficiency of trees because higher atmospheric $\mathrm{CO}_{2}$ levels reduce the amount of time that plants need to keep their stomata open (Keenan et al., 2013). Recent analyses of tropical trees suggest that concurrent with an increase in atmospheric $\mathrm{CO}_{2}$ levels over the past 150 years there is evidence of increased intrinsic efficiency in water use but not accelerated growth of individual trees (as revealed by the width of tree rings). The assumption that tree growth will be stimulated via $\mathrm{CO}_{2}$ fertilization therefore continues to be highly controversial (van der Sleen et al., 2015).

There may be other effects of climate change on large old trees. For example, given their inherent vulnerability to windthrow (Webb, 1988; Lugo, 2008) (in part because of their tall and stiff stature), large trees may be disadvantaged if windspeeds and intense storms increase in the future, as has been projected by some analyses (Young, Zieger \& Babanin, 
2011). Reduced rainfall and warming temperatures associated with climate change are leading to severe droughts with corresponding impacts on tree mortality (Millar \& Stephenson, 2015), such as in the boreal forests of western Canada (Chen \& Luo, 2015) and via severe droughts associated with increasing El Niño events in the western Pacific region (Power et al., 2013) and shifts in the inter-tropical convergence zone because of sea-surface warming. Such shifts caused droughts of unprecedented extent and magnitude in the Amazon basin in 2005 and again in 2010, killing hundreds of millions of trees and releasing several billion tonnes of atmospheric carbon emissions (Lewis et al., 2011) In regions such as southwestern Australia, reduced rainfall may depress groundwater on which some species of large old trees are reliant and preclude new cohorts of tree species like jarrah (Eucalyptus marginata) from attaining the size of past forest giants (Wardell-Johnson, 2016). In other ecosystems, climate-change-associated droughts may stimulate trees to alter carbon allocation away from bole growth to leaves and roots with consequent implications for long-term carbon storage and tree size (Anderegg et al., 2015).

\section{MULTIPLE INTERACTING THREATENING PROCESSES}

There can be important interactions among factors threatening populations of large old trees. For example, land-use practices and their effects such as selective logging, clearcut logging, and forest fragmentation can interact to increase the vulnerability of some ecosystems to destructive fires (Cochrane \& Laurance, 2008; Taylor, McCarthy \& Lindenmayer, 2014). It has also been suggested that large-scale drivers, such as regional or global changes in climate, can interact with land-use change, particularly habitat fragmentation and land clearing (McAlpine et al., 2007; Laurance et al., 2014). The decline of large old American beech (Fagus grandifolia) trees in parts of the north-eastern USA was caused by a combination of a fungus and an invasive scale insect (McNulty \& Masters, 
2005). The impacts of introduced or native pests, pathogens or disease vectors could be increased by climatic change; for instance, milder winters have allowed many species of bark beetles to proliferate in western North American coniferous forests. This, coupled with widespread forestry practices that favour particular beetle-susceptible tree species, is thought to underpin major increases in tree mortality (Raffa et al., 2008). Large old trees, which are preferentially attacked by the beetles, are especially vulnerable (Kashian et al., 2011). As a final example, logged and fragmented forests can be highly susceptible to defaunation via overhunting and population isolation (Redford, 1992), which in turn can negatively impact tree populations by reducing animal seed dispersers and increasing density-dependent seed and seedling mortality (Wright et al., 2000; Dirzo et al., 2014).

In summary, populations of large old trees are susceptible to an array of threatening processes. A fundamental part of management must be to tackle these processes. However, this will often be challenging as large old trees in many ecosystems are subject to multiple threats (Vanak et al., 2011) that can interact in cumulative, additive or multiplicative ways (sensu Didham et al., 2007). In addition, different threats will manifest in different ways in different ecosystems and tackling those threats requires ecosystem-specific actions. Multiple threatening processes also may have different effects on different life stages of trees, with large old trees particularly at risk from some factors. We therefore suggest that predicting and managing risks must extend beyond traditional approaches such as population viability analysis because, for some tree species, it is not a risk of extinction per se that is of concern, but rather the functional extinction of a particular (large old tree) growth stage. To the best of our knowledge no formal viability analysis has yet been conducted that focuses specifically on large old trees. We nevertheless argue that it is critical to predict the impacts of multiple threatening processes better because losses of the key roles played by large old trees may render some ecosystems vulnerable to collapse. For example, the rapid decline in large old 
tree populations in Australian-mainland mountain ash forests led to these ecosystems being formally classified as Critically Endangered under the IUCN Red List ecosystem methodology (Burns et al., 2015). There is little doubt that many other large old tree species and associated ecosystems worldwide would be assigned similar status under this IUCN ecosystem criterion. The largest tree species in the Arabian Peninsula, Mimusops laurifolia, is but one of many examples (Hall et al., 2010).

We have developed a simple conceptual framework for helping to meet some of the challenges associated with mitigating the multiple and often ecosystem-specific manifestations of multiple interacting threats facing large old trees (Fig. 4). Our framework is simple so as to facilitate its application and is characterized by explicit links and feedback loops between monitoring population decline, diagnosing the reasons for that decline (including interactions between key threatening processes), prioritizing and then implementing management actions to mitigate the impacts of these threats, and then monitoring the effectiveness of management interventions.

\section{CONSERVATION AND MANAGEMENT OF LARGE OLD TREES}

Beyond the problems created by multiple interacting threats, at least five other factors create major challenges in conserving populations of large old trees. (1) In broad terms, large trees are adapted for stability and longevity but these are increasingly rare commodities in the modern world. (2) The attributes that confer evolutionary advantages for features such as extreme height make large old trees vulnerable to various threats. For example, the prolonged time until reproduction in some species of large old trees (Lindenmayer et al., 2011; Thomas, 2011) means they can easily be eliminated from particular areas as a result of frequent disturbances such as recurrent high-severity wildfire. (3) Large old trees are obviously less mobile than animals; they may be growing in places that were suitable for germination 500- 
$1000+$ years ago but which are no longer suitable for new cohorts of trees. (4) Traditional approaches to management learning and identifying drivers of decline such as intervention experiments and adaptive management can be inoperable in the case of large old trees because of their rarity, cultural importance and an array of impaired ecosystem functions if they are lost. (5) Large old trees are strongly associated with old-growth forest ecosystems, but they are also critical organisms in desert, savanna, agricultural, and urban environments, each of which has different management needs, thereby creating enormous challenges in conservation of these keystone structures.

Given that large old trees are essentially irreplaceable structures in many ecosystems (Laurance et al., 2000), we assert that offset policies (Maron et al., 2015) for them will ultimately be flawed or at best highly limited in effectiveness. As an example, nest boxes and other kinds of artificial nest sites are sometimes touted as offsets for the loss of large old trees. Yet nest boxes provide for only one of the ecological roles of large old trees (cavity accessibility) and make no contribution to other roles such as carbon storage, pulses of flowering and seed dispersal, and providing food for a large array of fauna. In addition, many animal species do not occupy artificial cavities and the approach has not been employed for the majority of taxa of conservation concern. For instance, a survey we completed as part of this review showed that nest boxes have been deployed in the conservation of less than $1 \%$ of the world's $\sim 1350$ endangered IUCN listed cavity-dependent bird species. Moreover, recent work in urban settings has shown that nest boxes are clearly most beneficial when they are attached to large old trees (Le Roux et al., 2016), indicating that some fauna are responding to other attributes of these trees beyond cavity availability. Strategies that attempt to accelerate the development of large old trees such as stand thinning to promote growth and vine cutting to reduce competition do not promote the development of other key features of 
large old trees that require prolonged periods of time to accrue (such as internal levels of trunk decay) (Gibbons \& Lindenmayer, 2002).

Meeting the myriad challenges associated with the conservation of large old trees will demand novel management policies and strategies at scales ranging from individual trees through to landscape and regional levels as well as over prolonged periods of time. We touch on a small subset of possible approaches in the remainder of this section.

\section{(1) Tree-level actions}

Large old trees often occur as individual stems or small groups of trees [see Hall et al. (2010) for an example from the Middle East]. This is common in many desert, savanna, semicleared agricultural and urban environments. Protection of individual trees will often be critical in these environments, and traditional broader-scaled approaches like old-growth forest conservation will rarely apply in these contexts. The need for tree-level policies is emphasized by the possibility that the ecological or social value of a given large old tree will be higher where it is an isolated stem (for instance, in an agricultural field or urban streetscape) than when it occurs as part of a stand of large old trees (Fischer, Stott \& Law, 2010a; Le Roux et al., 2015). In terms of conserving these specimens, buffers of undisturbed vegetation around individual large old trees can be important. The size of these buffers needs to be directed by science that addresses the magnitude and penetration of edge effects, the pattern of spatial contagion in processes like fire that can damage large old trees, and other factors such as the transmission of pathogens associated with human access. El Grande in Tasmania - the largest known individual angiosperm in the world - was not appropriately buffered from human disturbance and was killed by nearby logging and fire (Lester, 2010).

Many government and community groups have developed policies and practices to conserve individual large old trees (Friends of Trees, 2016; Moga et al., 2016; Save the 
Redwoods League, 2016), but it is also important to ensure that sufficient numbers of young trees are recruited to maintain viable tree populations. This requires careful consideration of the kinds of trees to target as recruits, as these need to be individuals that have the highest probability of surviving and standing for the longest possible time. Perversely, in some ecosystems subject to logging operations, trees set aside for retention are those unsuitable for timber harvesting, yet these 'defective' trees can be highly susceptible to collapse (Gibbons, Cunningham \& Lindenmayer, 2008a).

An approach to promote the long-term maintenance of large old trees in woodproduction forest landscapes is the application of silvicultural systems that lead to the retention of parts of harvested stands. These include reduced intensity logging (RIL) in tropical areas (Putz et al., 2012) and variable retention harvesting in temperate and boreal forests (Lindenmayer et al., 2012b; Fedrowitz et al., 2014). In both cases, very large trees such as those above a set diameter can be excluded from logging (e.g. Sist et al., 2014). However, both reduced impact logging and variable retention harvesting can still generate significant issues with landscape fragmentation, edge effects and altered fire regimes, all of which can accelerate mortality and loss of large old trees (e.g. Laurance et al., 2000; Lindenmayer et al., 1990). They can also cause considerable stand damage (Mazzei et al, 2010) and major losses of carbon biomass associated with post-harvest mortality (Sist et al., 2014).

In agricultural landscapes, large old scattered trees can be better protected through localized fencing to reduce grazing pressure, soil compaction and excess nutrient input from dung from domestic livestock (Fischer et al., 2009). In urban settings, strategic pruning, the creation of safety zones for human access, and other practices can help to better protect large old trees (Ikin et al., 2015; Le Roux et al., 2016). 


\section{(2) Landscape-level actions}

A range of factors at landscape scales influence the distribution and abundance of large old trees. Landscape-level management is often required to accommodate the positive or negative effects of these factors. It can be particularly important to curtail the negative impacts of processes that exhibit strong patterns of spatial contagion and which can severely impact the occurrence and abundance of large old trees. These include spatial contagion in canopy gaps in tropical rainforests (Young \& Hubbell, 1991) and high-severity standreplacing fires such as those in wet temperate forests (Lindenmayer et al., 2011).

A key component of landscape management encompasses the landscape-level protection of places where large old trees are most likely to develop. These places can include refuges from fires, droughts and windstorms where large old trees have an increased probability of persisting (Mackey et al., 2012). For example, protecting mesic drought and fire refugia may be critical given the narrow hydraulic margins within which large old trees survive (Choat et al., 2012). However, recent work (Berry et al., 2015) has underscored the difficulties in predicting the occurrence of refugia at micro- and meso-scales, particularly in landscapes subject to high-severity disturbance. A further challenge will be to determine where refugia might exist in landscapes and ecosystems subject to rapid climate change. Therefore, key challenges remain in accurately predicting not only where large old trees are most likely to persist now, but also will occur in the future.

As outlined above, the places where large old trees presently exist may not be suitable for the development of new cohorts of the same species; appropriate current and future environmental domains may well exist in locations where that taxon does not presently occur or has never occurred. The future distribution and even persistence of large old trees may therefore demand that policy makers and tree managers consider highly controversial responses such as assisted colonization (via seeding or seedling planting) to new and 
previously unoccupied locales (Hoegh-Guldberg et al., 2008). This, in turn, will create novel ecosystems (Hobbs, Higgs \& Hall, 2013) in which large old trees become parts of species assemblages that have not previously existed. Both assisted colonization and the creation of novel ecosystems are highly contested solutions to conservation problems (Ricciardi \& Simberloff, 2008; Murcia et al., 2014) and thus identifying the best strategies for ensuring the long-term persistence of large old trees remains open for debate. Some non-trivial complications accompany assisted colonization and the conservation of large old trees. For example, some of the key characteristics of large old trees like large cavities arise through the activities of other species such as termites, fungi and woodpeckers. These species also may need to be moved alongside large old trees if cavity-development functions are to be maintained and the myriad taxa dependent on such cavities are to be supported. However, movement of multiple species that interact with the target tree species may not be required if other taxa with similar ecological roles are present to fulfil these functions.

\section{(3) Management actions over appropriate temporal scales}

The protection of large old trees spans unprecedented time frames for management and monitoring - many multiples of human lifespans and sometimes exceeding entire human civilizations! Yet, we argue there are probably few if any other organisms for which longterm monitoring is more crucial, given their prolonged lifespans, an urgent need to document their population dynamics and the multiple, interacting drivers of those dynamics, and the negative consequences of the loss of large old trees. Such long-term monitoring and management must not only protect existing large old trees but also ensure sufficient recruitment of new cohorts of trees. This addresses the two key components of the life cycle of large old trees - adult mortality and recruitment. Yet the record on sustaining long-term environmental monitoring is poor in all jurisdictions globally (Lindenmayer \& Likens, 2010; 
Muller et al., 2011) and even the longest-running programs fall many centuries short of the lifespan of most large old trees. For example, in many old-growth forests, the history of industrial logging is many centuries shorter than the lifespans of the trees being harvested. The need for monitoring over such unprecedented periods will require new ways of thinking about and funding monitoring, as well as innovative approaches to storing information to accommodate inevitable technological changes in data storage and curation. New ways of integrating more traditional approaches like long-term monitoring, remote sensing and dendrochronology also will be valuable for quantifying the responses of trees to environmental changes such as elevated levels of atmospheric $\mathrm{CO}_{2}$ and altered hydrological regimes (van der Sleen et al., 2015).

Finally, there will be important benefits for protecting large old trees generated from intersecting ecological and social values that often reinforce one another (Blicharska \& Mikusinski, 2014). As an example, citizen science can be an excellent vehicle for fostering support for education about, and the protection of, large old trees. For instance, the assistance of schools from more than 20 villages helped to locate, measure and photograph more than 1600 of the largest and oldest trees in wooded pastures in southern Transylvania, Romania (Moga et al., 2016; http://arboriremarcabili.ro/en/trees). Large old trees may be better protected if they are allocated special status, such as in major initiatives like the UNESCO World Heritage for which criteria vii and x apply to large old trees (see http://whc.unesco.org/en/criteria/). An example is the 1000+ year-old Japanese cedar (Cyrptomeria japonica) in the Yakusugi forests in Yakushima, Japan (http://whc.unesco.org/en/list/662). Large old trees also might be better protected if their loss is formally recognized as part of processes triggering ecosystem collapse, such as under formal IUCN Ecosystem Assessment procedures (Keith et al., 2013). Furthermore, improved protection might be afforded by better communicating ecological and socio-economic 
opportunities and advantages generated by expanding populations of large old trees, such as increasing above-ground biomass and carbon storage (Kauppi et al., 2015). In addition, the social and economic value of large old trees could be underscored via their utility as indicators or surrogates (sensu Caro, 2010) of environmental changes; for example, their deep root systems may mean that they respond early to problems such as rising water tables and secondary salinity (Stirzaker, Vertessey \& Sarre, 2002) (Table S1). However, this potential indicator role needs to be used cautiously; for example, the apparent ability of large old trees to adapt to long-term changes (Phillips et al., 2008) may render them unsuitable as robust environmental surrogates.

\section{CONCLUSIONS}

(1) Large old trees have long fascinated humans and have a key place in our culture and psyche (Blicharska \& Mikusinski, 2014; Moga et al., 2016). Yet much remains to be learned from large and old trees. Indeed, even entirely new species of large old trees may await discovery; the 30 m-tall Bartlett's rata (Metrosideros bartlettii) was identified only relatively recently in the far north of New Zealand (Drummond et al., 2000).

(2) The same features of large old trees that captivate humans such as their extreme longevity and size also create enormous challenges for their measurement, monitoring and conservation, as does their rarity and susceptibility to rare events. Large old trees play such a wide array of important ecological and environmental roles that it is hugely challenging simply to document them (Table S1). Given their adaptations for stability and longevity, and often specialized environmental and life-history requirements, large old trees may be bellwethers for change in a rapidly changing world.

(3) There is a need for new management paradigms and sets of human values to better protect large old trees. For example, the long-term importance of large old trees for accumulating and 
storing vast amounts of carbon needs to be better recognized, particularly in terms of preventing them being replaced by faster-growing stands of younger trees. In addition, society needs to appreciate better that decay in large old trees is a natural process and creates important structural characteristics that are essential to many key ecological processes and roles. Hence, being large and decayed should not be used as an ill-informed trigger to remove large old trees.

(4) One point, however, is clear. Once lost from an ecosystem, populations of large old trees are inherently difficult (and sometimes impossible) to recover, as are their many associated ecological and cultural roles. Large old trees require both long periods of time and relative environmental stability, including amelioration of the often-chronic and large-scale processes that threaten them. For such reasons, it is clear that a precautionary approach is essential when managing large old trees.

\section{ACKNOWLEDGMENTS}

We thank a wide range of colleagues for discussions and supply of information. These include Mark Westoby, Robert Heinsohn, Paul Nelson, Saul Cunningham, Rick Shine, and David Coates. Tabitha Boyer and Claire Shepherd assisted with manuscript preparation. Comments by Tibor Hartel and an anonymous reviewer improved the manuscript.

\section{REFERENCES}

Acker, S. A., Boetsch, J. R., Bivin, M., Whiteaker, L., Cole, C. \& PhilipPi, T. (2015). Recent tree mortality and recruitment in mature and old-growth forests in western Washington. Forest Ecology and Management 336, 109-118.

ALDRICH, P. R. \& HAMRICK, J. L. (1998). Reproductive dominance of pasture trees in a fragmented tropical forest mosaic. Science 281, 103-105. 
Allen, C. D., Macalady, A. K., Chenchouni, H., Bachelet, D., McDowell, N., Vennetier, M., Kitzberger, T., Rigling, A., Breshears, D. D., HogG, E. H., Gonzalez, P., Fensham, R., Zhang, Z., Castro, J., Demidova, N., Et al. (2010). A global review of drought and heat-induced tree mortality reveals emerging climate change risks for forests. Forest Ecology and Management 259, 660-664.

AnderegG, W. R. L., KAne, J. M. \& AnderegG, L. D. L. (2013). Consequences of widespread tree mortality triggered by drought and temperature stress. Nature Climate Change 3, 30-36.

AnderegG, W. R. L., Schwalm, C., Biondi, F., Camarero, J. J., Koch, G., LitvaK, M., Ogle, K., Shaw, J. D., Shevliakova, E., Williams, A. P., Wolf, A., Ziaco, E. \& PACALA, S. (2015). Pervasive drought legacies in forest ecosystems and their implciations for carbon cycle models. Science 349, 528-532.

Anderson, R. M. \& MAy, R. M. (1982). Coevolution of hosts and parasites. Parasitology 85, $411-426$.

ASHTON, D. (1975). The root and shoot development of Eucalyptus regnans F. Muell. Australian Journal of Botany 23, 867-887.

BANKS, J. C. (1993). Tree-ring analysis of two Mountain Ash trees Eucalyptus regnans F.Muell from the Watts and O'Shannassy Catchments, Central Highlands, Victoria. A Report to the Central Highlands Old Growth Forest Project. August 1993. Department of Conservation and Natural Resources, Melbourne, Australia.

Barlow, J., Peres, C. A., Lagan, B. O. \& Haugaasen, T. (2003). Large tree mortality and the decline of forest biomass following Amazonian wildfires. Ecology Letters 6, 6-8. BELl, D. T. (1999). Turner Review No. 1: The process of germination in Australian species. Australian Journal of Botany 47, 475-517. 
Bell, T. J., Bowles, M. L. \& McEachern, A. K. (2003). Projecting the success of plant population restoration with viability analysis In Population Viability in Plants: Conservation, Management, and Modeling of Rare Plants, vol. Ecological Studies 165 (ed. C. A. Brigham and M. W. Schwartz). Springer-Verlag, Berlin.

Bello, C., Galetti, M., Pizo, M. A., Magnago, L. F. S., Rocha, M. F., Lima, R. A. F., Peres, C. A., Ovaskainen, O. \& Jordano, P. (2015). Defaunation affects carbon storage in tropical forests. Science Advances 1, e1501105.

Berry, L. E., Driscoll, D. A., Stein, J. A., Blanchard, W., Banks, S. C., Bradstock, R. A. \& LindenMAYER, D. B. (2015). Identifying the location of fire refuges in wet forest ecosystems. Ecological Applications 25, 2237-2348.

Bhagwat, S.A., Breman, E., Thekaekara, T., Thornton, T. F. \& Willis, K. J. (2012). A battle lost? Report on two centuries of invasion and management of Lantana camara L. in Australia, India and South Africa. PLoS ONE 7, e32407. doi:10.1371/journal.pone.0032407.

BLICHARSKA, M. \& MiKUSINSKI, G. (2014). Incorporating social and cultural significance of large old trees in conservation policy. Conservation Biology 28, 1558-1567.

BLUFF, L. (2016). Reducing the effect of planned burns on hollow-bearing trees. Fire and adaptive management Report No. 95. Department of Environment, Land and Water Planning. Melbourne, Australia.

BouZAT, J. L. (2010). Conservation genetics of population bottlenecks: the role of chance, selection, and history. Conservation Genetics 11, 139-147.

Bowman, D. (2012). Bringing elephants to Australia? Nature 482, 30.

Bowman, D., MacDermott, H., Nichols, S. \& Murphy, B. (2014). A grass-fire cycle eliminates an obligate-seeding tree in a tropical savanna. Ecology \& Evolution 4, $4185-4194$. 
Briant, G., Gond, V. \& LAURANCE, S. G. W. (2010). Habitat fragmentation and the desiccation of forest canopies: a case study from eastern Amazonia. Biological Conservation 143, 2763-2769.

BrÄutigam, K., Vining, K.J., Lafon-Placette, C., Fossdal, C.G., Mirouze, M., Marcos, J.G., Fluch, S., Fraga, M.F., Guevara, M.Á., Abarca, D., Johnsen, O., Maury, S., Strauss, S.H., CAMPBELl, M.M., RoHDE, A., ET AL. (2013). Epigenetic regulation of adaptive responses of forest tree species to the environment. Ecology and Evolution 3, $399-415$.

BRIENEN, R. J. W. \& ZUIDEMA, P. A. (2006) Life time growth patterns and ages of Bolivian rain forest trees obtained by tree ring analysis. Journal of Ecology 98, 481-493.

BROKAW, N. V. \& LENT, R. A. (1999). Vertical structure. In Managing Biodiversity in Forest Ecosystems (ed. M. Hunter), pp. 373-399. Cambridge University Press, Cambridge.

Burns, E. L., LindenMayer, D. B., Stein, J., Blanchard, W., McBurney, L., Blair, D. \& BANKS, S. C. (2015). Ecosystem assessment of mountain ash forest in the Central Highlands of Victoria, south-eastern Australia. Austral Ecology 40, 386-399.

CARO, T. (2010). Conservation by Proxy. Indicator, umbrella, keystone, flagship, and other surrogate species. Island Press, Washington D.C.

Carpaneto, G. M., Mazziotta, A., Coletti, G., Luiselli, L. \& Audisio, P. (2010). Conflict between insect conservation and public safety: the case study of a saproxylic beetle (Osmoderma eremita) in urban parks. Journal of Insect Conservation 14, 555-565.

Cecile, J., Silva, L. R. \& ANAND, M. (2013). Old trees: large and small. Science 339, 904905.

Chambers, J.Q., Higuchi, N. \& Schimel, J. P. (1998). Ancient trees in Amazonia. Nature 39, 135-136. 
Chambers, J. Q., Van Eldik, T., Southon, J. \& Higuchi, N. (2001). Tree age structure in tropical forests of central Amazonia. In Lessons from Amazonia: Ecology and Conservation of a Fragmented Forest (Eds. Bierregaard, R. O., Gascon, C., Lovejoy, T., Mesquita, R.), pp. 68-78. Yale University Press, New Haven, Connecticut, USA.

Chen, H. Y. H. \& LuO, Y. (2015). Net aboveground biomass declines of four major forest types with forest ageing and climate change in western Canada's boreal forests. Global Change Biology 21, 3675-3684.

CHESSON, P. \& WARNER, R. (1981). Environmental variability promotes coexistence in lottery competitive systems. The American Naturalist 117, 923-943.

Choat, B., Jansen, S., Brodribb, T. J., Cochard, H., Delzon, S., Bhaskar, R., Bucci, S. J., Feild, T. S., Gleason, S. M., Hacke, U. G., Jacobsen, A. L., Lens, F., Maherali, H., MartineZ-Vilalta, J., MAYR, S., ET AL. (2012). Global convergence in the vulnerability of forests to drought. Nature 491, 752-755.

Clark, D. A., Piper, S. C., Keeling, C. D. \& Clark, D. B. (2003). Tropical rain forest tree growth and atmospheric carbon dynamics linked to interannual temperature variation during 1984-2000. Proceedings of the National Academy of Sciences 100, 58525857.

CLARK, D. B. \& CLARK, A. C. (1996). Abundance, growth and mortality of very large trees in neotropical lowland rain forest. Forest Ecology and Management 80, 235-244.

Cochrane, M. A. \& Laurance, W. F. (2008). Synergisms among fire, land use, and climate change in the Amazon. Ambio 37, 522-527.

Cockle, K. L., MARTin, K. \& Wesolowski, T. (2011). Woodpeckers, decay, and the future of cavity-nesting vertebrate communities worldwide. Frontiers in Ecology and the Environment 9, 377-382. 
Condit, R., Hubbell, S. P. \& Foster, R. B. (1995). Mortality rates of 205 neotropical tree and shrub species and the impact of a severe drought. Ecological Monographs 65, $419-439$.

Crane, M., Lindenmayer, D. B., Cunningham, R. B. \& Stein, J. (2016). The effect of wildfire on "keystone structures" in agricultural landscapes. Austral Ecology in press.

Crowe, M. P., PAXton, J. \& Tyers, G. (1984). Felling dead trees with explosives. Australian Forestry 47, 84-87.

Crowther, T. W., Glick, H. B., Covey, K. R., Bettigole, C., Maynard, D. S., Thomas, S. M., Smith, J. R., Hintler, G., Duguid, M. C., Amatulli, G., Tuanmu, M.-N., Jetz, W., SAlas, C., Stam, C., Piotto, D., ET AL. (2015). Mapping tree density at a global scale. Nature 525, 201-205.

Cushman, K. C., Muller-Landau, H. C., Condit, R. S. \& Hubbell, P. (2014). Improving estimates of biomass change to buttressed trees using tree taper models. Methods in Ecology and Evolution 5, 573-582.

D'Amato, A. W. \& Orwig, D. A. (2008). Stand and landscape-level disturbance dynamics in old-growth forests in western Massachusetts. Ecological Monographs 78, 507-522.

D'Amato, A. W., Orwig, D. A. \& Foster, D. R. (2009). Understorey vegetation in oldgrowth and second-growth Tsuga canadensis forests in western Massachusetts. Forest Ecology and Management 257, 1043-1052.

DaszaK, P., Cunningham, A. A. \& HyatT, A. D. (2000). Emerging infectious diseases of wildlife - threats to biodiversity and human health. Science $\mathbf{2 8 7}, 443-449$.

DeAn, W. R., Milton, S. J. \& Jeltsch, F. (1999). Large trees, fertile islands, and birds in arid savanna. Journal of Arid Environments 41, 61-78. 
Dick, C. W., HARdy, O. J., Jones, R. A. \& Petit, R. J. (2008). Spatial scales of pollen and seed-mediated gene flow in tropical rain forest trees. Tropical Plant Biology 1, 20-33.

Didham, R., Tylianakis, J. M., Gemmell, N. J., Rand, T. A. \& Ewers, R. M. (2007). Interactive effects of habitat modification and species invasion on native species decline. Trends Ecology \& Evolution 22, 489-496.

Dirzo, R., Young, H. S., Galetti, M., Ceballos, G., IsaAC, N. J. B. \& Collen, B. (2014). Defaunation in the Anthropocene. Science 345, 401-406.

DRENT, P. J. (1984). Mortality and dispersal in summaer and its consequences for the denity of Great Tits, Parus major, at the onset of autumn. Ardea 72, 127-162.

Drummond, R. S., Keeling, D. J., Richardson, T. E., GARdner, R. C. \& Wright, S. D. (2000). Genetic analysis and conservation of 31 surviving individuals of a rare New Zealand tree, Metrosideros bartlettii (Myrtaceace). Molecular Ecology 9, 1149-1157.

ELITH, J. \& LEATHWICK, J. R. (2009). Species distribution models: ecological explanation and prediction across space and time. Annual Review of Ecology, Evolution, and Systematics 40, 677-697.

Eveleth, R. (2012). How one man accidentally killed the oldest tree ever. Smithsonian.com, http://www.smithsonianmag.com/smart-news/how-one-man-accidentally-killed-theoldest-tree-ever-125764872/?no-ist.

FAIRWEAther, A.A., Brockie, R.E. \& WARD, D.G. (1986). Possums (Trichosurus vulpecula) sharing dens: a potential infection route for bovine tuberculosis, New Zealand Veterinary Journal 35, 15-16.

FAshing, P. J., ForRestel, A., SCUlly, C. \& CORDS, M. (2004). Long-term tree population dynamics and their implciations for the conservation of the Kakamega Forest, Kenya. Biodiversity and Conservation 13, 753-771. 
Fedrowitz, K. F., Koricheva, J., Baker, S. C., Lindenmayer, D. B., Palik, B., Rosenvald, R., Beese, W., Franklin, J. F., Kouki, J., Macdonald, E., Messier, C., Sverdrup-Thygeson, A. \& Gustafsson, L. (2014). Can retention forestry help conserve biodiversity? A meta-analysis. Journal of Applied Ecology 51, 1669-1679.

Fischer, J., StotT, J. \& LAW, B. S. (2010a). The disproportionate value of scattered trees. Biological Conservation 143, 1564-1567.

Fischer, J., Stott, J., Zerger, A., WArren, G., Sherren, K. \& Forrester, R. I. (2009). Reversing a tree regeneration crisis in an endangered ecoregion. Proceedings of the National Academy of Sciences 106, 10386-10391.

Fischer, J., Zerger, A., Gibbons, P., Stott, J. \& LAW, B. S. (2010b). Tree decline and the future of Australian farmland biodiversity. Proceedings of the National Academy of Sciences 107, 19597-19602.

Fischer, W. C. \& MCClelland, B. R. (1983). Cavity-nesting bird bibiography including related titles on forest snags, fire, insects, diseases and decay. Intermountain Forest and Range Experiment Station, Ogden, Utah.

Forman, R. T. (2014). Urban ecology. Cambridge University Press, Cambridge, England.

Franklin, J. F., Cromack, K. J., Denison, W., McKee, A., Maser, C., Sedell, J., SWANSON, F. \& JUDAY, G. (1981). Ecological attributes of old-growth Douglas-fir forests. In USDA Forest Service General Technical Report PNW-118. Pacific Northwest Forest and Range Experimental Station, Portland, Oregon.

Franklin, J. F., Lindenmayer, D. B., MacMahon, J. A., McKee, A., Magnuson, J., Perry, D. A., Waide, R. \& Foster, D. R. (2000). Threads of continuity. Conservation in Practice 1, 8-17.

Franklin, J. F., Spies, T. A., van Pelt, R., Carey, A. B., Thornburgh, D. A., Berg, D. R., Lindenmayer, D. B., Harmon, M. E., Keeton, W. S., Shaw, D. C., Bible, K. \& 
CHEN, J. (2002). Disturbances and the structural development of natural forest ecosystems with silvicultural implications, using Douglas-fir forests as an example. Forest Ecology and Management 155, 399-423.

FRIENDS OF TREES (2016). Save the Giant Sequoias. Friends of Trees, https://friendsoftrees.org/donate-today-eastmoreland.

Fritz, S. A., BinindA-EMONDS, O. R. P. \& PURVIS, A. (2009). Geographical variation in predictors of mammalian extinction risk: big is bad, but only in the tropics. Ecology Letters 12, 538-549.

George, A. K., WALKer, K. F. \& LeWIS, M. M. (2005). Population status of eucalypt trees on the River Murray floodplain South Australia. River Restoration and Applications 21, $271-282$.

Gibbons, P., Briggs, S. V., Murphy, D. Y., Lindenmayer, D. B., McElhinny, C. \& BRoOKHOUSE, M. (2010). Benchmark stem densities for forests and woodlands in south-eastern Australia under conditions of relatively little modification by humans since European settlement. Forest Ecology and Management 260, 2125-2133.

Gibbons, P., Cunningham, R. B. \& Lindenmayer, D. B. (2008a). What factors influence the collapse of trees retained on logged sites: a case-control study. Forest Ecology and Management 255, 62-67.

Gibbons, P. \& Lindenmayer, D. B. (2002). Tree Hollows and Wildlife Conservation in Australia. CSIRO Publishing, Melbourne.

Gibbons, P., Lindenmayer, D. B., Fischer, J., Manning, A. D., Weinberg, A., Seddon, J., RYAN, P. \& BARRETT, G. (2008b). The future of scattered trees in agricultural landscapes. Conservation Biology 22, 1309-1319.

GibBS, J. P., Hunter, M. \& Melvin, S. M. (1993). Snag availability and communities of cavity nesting birds in tropcial versus temperate forests. Biotropica 25, 236-241. 
GroenendiJk, P., Sass-KlaAssen, U., Bongers, F. \& Zuidema, P. A. (2014). Potential of tree-ring analysis in a wet tropical forest: A case study on 22 commercial tree species in Central Africa. Forest Ecology \& Management 323, 65-78.

Hall, M., Neale, T., Al-AbBasi, M. \& Miller, A. G. (2010). Arabia's tallest trees: ecology, distribution and conservation status of the regionally endangered tree species Mimusops laurifolia. Nordic Journal of Botany 28, 240-245.

Harmon, M., Franklin, J. F., Swanson, F., Sollins, P., Gregory, S. V., Lattin, J. D., Anderson, N. H., Cline, S. P., Aumen, N. G., Sedell, J. R., Lienkaemper, G. W., Cromack, K. \& Cummins, K. (1986). Ecology of coarse woody debris in temperate ecosystems. Advances in Ecological Research 15, 133-302.

Hirayama, D., NAAmi, S., Itoh, A. \& YAmakURA, T. (2008). Individual resource allocation to vegetative growth and reproduction in subgenus Cyclobalanopsis (Quercus, Fagaceae) trees. Ecological Research 23, 451-458.

Hobbs, R. J., Higgs, E. S. \& Hall, C. M. (2013). Novel Ecosystems: Intervening in the New World Order. Wiley, Oxford.

Hoegh-Guldberg, O., Hughes, L., McIntyre, S., Lindenmayer, D. B., Parmesan, C., Possingham, H. P. \& Thomas, C. D. (2008). Assisted colonization and rapid climate change. Science 321, 345-346.

Ikin, K., Mortelliti, A., Stein, J. R., Michael, D., Crane, M., OKada, S., WoOd, J. \& LINDENMAYER, D. B. (2015). Woodland habitat structures are affected by both agricultural land management and abiotic conditions. Landscape Ecology 30, 13871403.

InIONS, G., TANTON, M. T. \& DAVEY, S. M. (1989). Effects of fire on the availability of hollows in trees used by the Common Brushtail Possum, Trichosurus vulpecula Kerra 
1792, and the Ringtail Possum, Pseudocheirus peregrinus Boddaerts 1785. Australian Wildlife Research 16, 449-458.

ISSARTEL, J. \& COIFFARD, C. (2011). Extreme longevity in trees: live slow, die old? Oecologia 165, 1-5.

JANZEN, D. H. (1986). The future of tropical biology. Annual Review of Ecology and Systematics 17, 305-324.

JayaseKara, P., WeErasinghe, U. R., WiJesundara, S. \& TAKATSuKi, S. (2007). Identifying duirnal of nocturnal frugivores in the terrestrial and arboreal layers of a tropical forest in Sri Lanka. Ecotropica 13, 7-15.

JONES, R. H. (1997). Staus and habitat of big trees in Congaree Swamp national Monument. Castanea 62, 22-31.

Jordan, G. J., Potts, B. M., Chalmers, P. \& Wiltshire, R. J. E. (2000). Quantitative evidence that the timing of the vegetative phase change in Eucalyptus globulus spp. globulus is an adaptive trait. Australian Journal of Botany 48, 561-567.

KAPOS, V. (1989). Effects of isolation on the water status of forest patches in Brazilian Amazonia. Journal of Tropical Ecology 5, 173-185.

Kartzinel, T. R., Trapnell, D. W. \& ShefFERson, R. P. (2013). Critical importance of large native trees for conservation of a rare Neotropical epiphyte. Journal of Ecology 101, $1429-1438$.

KASHIAN, D. M., JACKSON, R. M. \& LyONS, H. D. (2011). Forest structure altered by mountain pine beetle outbreaks affects subsequent attack in a Wyoming lodgepole pine forest, USA. Canadian Journal of Forest Research 41, 2403-2412.

Kauppi, P. E., Birdsey, R. A., PAn, Y., Ihalainen, A., Nojd, P. \& Lehtonen, A. (2015). Effects of land management on large trees and carbon stocks. Biogeosciences 12, 855-862. 
KAURI DieBACK (2012). The Facts on Kauri Dieback. Kauri Dieback Programme, http://www.kauridieback.co.nz/media/32880/kauridiebackqafactsheet.pdf.

KAVANAGH, R. P. \& TURNER, R. J. (1994). Birds in eucalypt plantations: the likely role of retained habitat trees. Australian Birds 28, 32-40.

KEELEY, J. E. (2009). Fire intensity, fire severity and burn severity: a brief review and suggested usage. International Journal of Wildland Fire 18, 116-126.

Keenan, T. F., Hollinger, D. Y., Bohrer, G., Dragoni, D., Munger, J. W., Schmid, H. P. \& RiCHARDSON, A. D. (2013). Increase in forest water-use efficiency as atmospheric carbon dioxide concentrations rise. Nature 499, 324-327.

Keith, D. A., Rodríguez, J. P., RodrígueZ-Clark, K. M., Nicholson, E., AaPAla, K., Alonso, A., Asmussen, M., Bachman, S., Bassett, A., Barrow, E. G., Benson, J. S., Bishop, M. J., Bonifacio, R., Brooks, T. M., Burgman, M. A., Et AL. (2013). Scientific foundations for an IUCN Red List of Ecosystems. PLOS One 8, e62111. Keith, H., Lindenmayer, D. B., Mackey, B. G., Blair, D., Carter, L., McBurney, L., OKADA, S. \& KONISHI-NAGANO, T. (2014a). Accounting for biomass carbon stock change due to wildfire in temperate forest landscapes in Australia. PLOS One 9, e107126.

Keith, H., Lindenmayer, D.B., Mackey, B.G., Blair, D., CARter, L,. McBurney, L., OKADA, S. \& KONISHI-NAGANO, T. (2014b). Managing temperate forests for carbon storage: impacts of logging versus forest protection on carbon stocks. Ecosphere $\mathbf{5}$ (6), 75.

Keith, H., LindenMayer, D.B., Macintosh, A. \& Mackey, B. (2015). Under what circumstances do wood products from native forests benefit climate change mitigation? PLOS One 10, e0139640. 
Keith, H., MACKey, B. G. \& LindenMAYER, D. B. (2009). Re-evaluation of forest biomass carbon stocks and lessons from the world's most carbon-dense forests. Proceedings of the National Academy of Sciences 106 (28) 11635-11640.

Killey, P., McElhinny, C., RAyner, I. \& WoOd, J. (2010). Modelling fallen branch volumes in a temperate eucalypt woodland: implications for large senescent trees and benchmark loads of coarse woody debris. Austral Ecology 35, 956-968.

Koch, G. W., Sillett, S. C., Antoine, M. E. \& Williams, C. B. (2015). Growth maximization trumps maintenance of leaf conductance in the tallest angiosperm. Oecologia 177, 321-331.

KrawChuK, M. A. \& CUMmInG, S. G. (2009). Disturbance history affects lightning fire initiation in the mixedwood boreal forest: observations and simulations. Forest Ecology and Management 257, 1613-1622.

Laurance, W. F., Andrade, A., Magrach, A., Camargo, J., Campbell, M., Fearnside, P. M., Edwards, W., Valsko, J., Lovejoy, T. E. \& Laurance, S. G. (2014). Apparent environmental synergism drives the dynamics of Amazonian forest fragments. Ecology 95, 3018-3026.

Laurance, W. F., Andrade, A. S., Magrach, A., Camargo, J. L. C., Valsko, J. J., Campbell, M., Fearnside, P. M., Edwards, W., Lovejoy, T. E. \& Laurance, S. G. (2013). Long-term changes in liana abundance and forest dynamics in undisturbed Amazonian forests. Ecology 95, 1604-1611.

Laurance, W. F., Delamonica, P., Laurance, S. G., Vasconcelos, H. L. \& Lovejoy, T. E. (2000). Rainforest fragmentation kills big trees. Nature 404, 836.

Laurance, W. F., Lovejoy, T. E., Vasconcelos, H. L., Bruna, E. M., Didham, R. K., Stouffer, P. C., Gascon, C., Bierregaard, R. O., Laurance, S. G. \& Sampaio, E. 
(2002). Ecosystem decay of Amazonian forest fragments: a 22-year investigation. Conservation Biology 16, 605-601.

Laurance, W. F., Nascimento, H. E. M., Laurance, S. G., Condit, R., D’Angelo, S. \& ANDRADE, A. (2004a). Inferred longevity of Amazonian rainforest trees based on a long-term demographic study. Forest Ecology and Management 190, 131-143.

Laurance, W. F., Oliveira, A. A., Laurance, S. G., Condit, R., Nascimento, H. E. M., SAnchez-Thorin, A. C., Lovejoy, T. E., Andrade, A., D'Angelo, S., Ribeiro, J. E. \& Dick, C. W. (2004b). Pervasive alteration of tree communities in undisturbed Amazonian forests. Nature 428, 171-175.

Laurance, W. F., Perez-Salicrup, D., Delamonica, P., Fearnside, P. M., D’Angelo, S., Jerozolinski, A., Pohl, L. \& Lovejoy, T. E. (2001). Rain forest fragmentation and the structure of Amazonian liana communities. Ecology 82, 105-116.

LEAK, W. B. (1985). Relationships of tree age to diameter in old-growth northern hardwoods and spruce-fir. USDA Forest Service, Research Note NE-329, Durham, New Hampshire, USA.

Le Roux, D., Ikin, K., Lindenmayer, D. B., Manning, A. D. \& Gibbons, P. (2015). Single large or several small? Applying biogeographic principles to tree-level conservation and biodiversity offsets. Biological Conservation 191, 558-566.

Le Roux, D., Ikin, K., Lindenmayer, D. B., Bistricer, G., Manning, A. D. \& Gibbons, P. (2016). Enriching small trees with artificial nest boxes cannot mimic the value of large trees for hollow-nesting birds. Restoration Ecology 24, 252-258.

LEIGHTON, M. \& WiRAWAN, N. (1986). Catastrophic drought and fire in Borneo tropical rain forest associated with the 1982-1983 El Nino-Southern Oscillation event. In Tropical rain forests and the world atmosphere (ed. G. T. Prance), pp. 75-102. AAAS Symposium 10, Boulder, Colorado. 
LESTER, L. (2010). Big tree, small news: media access, symbolic power and strategic intervention. Journalism 11, 589-606.

Lewis, S. L., Brando, P. M., Phillips, O. L., van der Heijden, G. M. F. \& NePstad, D. (2011). The 2010 Amazon drought. Science 331, 554.

Lewis, S. L., Lloyd, J., Sitch, S., Mitchard, E. T. \& LAurance, W. F. (2009a). Changing ecology of tropical forests: evidence and drivers. Annual Review of Ecology and Systematics 40, 529-549.

Lewis, S. L., Lopez-Gonzalez, G., Sonke, B., Affum-BAffoe, K., BAKer, T. R., Ojo, L. O., Phillips, O. L., Reitsma, J. M., White, L., Comiskey, J. A., K, M.-N. D., Ewango, C. E. N., FeldPausch, T. R., Hamilton, A. C., Gloor, M., ET AL. (2009). Increasing carbon storage in intact African tropical forests. Nature 457, 1003-1006.

LEWIS, S. L., MALHI, Y. \& PHILliPS, O. L. (2004). Fingerprinting the impacts of global change on tropical forests. Philosophical Transactions of the Royal Society B: Biological Sciences 359, 437-462.

Lindenmayer, D. B., Barton, P. S., Lane, P. W., Westgate, M. J., McBurney, L., Blair, D., GiBBOns, P. \& LiKens, G. E. (2014). An empirical assessment and comparison of species-based and habitat-based surrogates: A case study of forest vertebrates and large old trees. PLOS One 9, e89807.

Lindenmayer, D. B., Blair, D., McBurney, L. \& Banks, S. (2015). Mountain Ash. Fire, Logging and the Future of Victoria's Giant Forests. CSIRO Publishing, Melbourne.

Lindenmayer, D. B., Blanchard, W., Blair, D., McBurney, L. \& Banks, S. (2016). Environmental and human drivers influencing large old tree abundance in Australian wet forests. Forest Ecology and Management. doi.org/10.1016/j.foreco.2016.04.017. 
Lindenmayer, D. B., Blanchard, W., McBurney, L., Blair, D., Banks, S., Likens, G. E., FrAnKLIn, J. F., Stein, J. \& GibBOnS, P. (2012a). Interacting factors driving a major loss of large trees with cavities in an iconic forest ecosystem. PLOS One 7, e41864.

Lindenmayer, D. B., Cunningham, R. B. \& Donnelly, C. F. (1997). Decay and collapse of trees with hollows in eastern Australian forests: impacts on arboreal marsupials. Ecological Applications 7, 625-641.

Lindenmayer, D. B., Cunningham, R. B., Donnelly, C. F. \& Franklin, J. F. (2000). Structural features of old-growth Australian montane ash forests. Forest Ecology and Management 134, 189-204.

Lindenmayer, D. B., Cunningham, R. B., Donnelly, C. F., TAnton, M. T. \& NiX, H. A. (1993). The abundance and development of cavities in Eucalyptus trees: a case-study in the montane forests of Victoria, southeastern Australia. Forest Ecology and Management 60, 77-104.

Lindenmayer, D. B., Cunningham, R. B., Nix, H. A., TAnton, M. T. \& Smith, A. P. (1991a). Predicting the abundance of hollow-bearing trees in montane ash forests of southeastern Australia. Australian Journal of Ecology 16, 91-98.

Lindenmayer, D. B., Cunningham, R. B., Tanton, M. T. \& Smith, A. P. (1990). The conservation of arboreal marsupials in the montane ash forests of the Central Highlands of Victoria, southeast Australia: II. The loss of trees with hollows and its implications for the conservation of Leadbeater's Possum Gymnobelideus leadbeateri McCoy (Marsupialia: Petauridae). Biological Conservation 54, 133-145.

Lindenmayer, D. B., Franklin, J. F., Lõhmus, A., BAKer, S., BAuhus, J., Beese, W., Brodie, A., Kiehl, B., Kouki, J., Martínez Pastur, G., Messier, C., Neyland, M., Palik, B., Sverdrup-Thygeson, A., Volney, J., ET AL. (2012b). A major shift to 
retention forestry can help resolve global forest sustainability issues. Conservation Letters 5, 421-431.

Lindenmayer, D. B., Hobbs, R. J., Likens, G. E., Krebs, C. \& BAnKs, S. (2011). Newly discovered landscape traps produce regime shifts in wet forests Proceedings of the National Academy of Sciences 108, 15887-15891.

LINDENMAYER, D. B. \& LIKENS, G. E. (2010). Effective ecological monitoring. CSIRO Publishing, Canberra, Australia.

LindenMAYer, D. B., MACKEY, B. \& NIX, H. A. (1996). Climatic analyses of the distribution of four commercially-important wood production eucalypt trees from south-eastern Australia. Australian Forestry 59, 11-26.

Lindenmayer, D. B., Nix, H. A., McMahon, J. P., Hutchinson, M. F. \& Tanton, M. T. (1991b). The conservation of Leadbeater's Possum, Gymnobelideus leadbeateri (McCoy): a case study of the use of bioclimatic modelling. Journal of Biogeography 18, 371-383.

LINDO, Z. \& WHITELEY, J. A. (2011). Old trees contribute bio-available nitrogen through canopy bryophytes. Plant and Soil 342, 141-148.

LORTIE, C. J. (2014). Formalized synthesis opportunities for ecology: systematic reviews and meta-analyses. Oikos 123, 897-902.

Louv, R. (2005). Last Child in the Woods: Saving Our Children from Nature-Deficit Disorder. Algonquin Books of Chapel Hill, Chapel Hill, North Carolina.

LugO, A. (2008). Visible and invisible effects of hurricanes on forest ecosystems: an international review. Austral Ecology 33, 368-398.

LutZ, J. A., VAN WAgTENDONK, J. W. \& FrankLIN, J. F. (2009). Twentieth-century decline of large-diameter trees in Yosemite National Park, California, USA. Forest Ecology and Management 257, 2296-2307. 
Mackey, B., Berry, S., Hugh, S., Ferrier, S., Harwood, T. D. \& Williams, K. J. (2012). Ecosystem greenspots: identifying potential drought, fire, and climate-change microrefuges. Ecological Applications 22, 1852-1864.

Mackey, B., Lindenmayer, D. B., Gill, A. M., McCarthy, M. A. \& Lindesay, J. A. (2002). Wildlife, Fire and Future Climate: A Forest Ecosystem Analysis. CSIRO Publishing, Melbourne.

Macintosh, A., KeIth, H. \& LindenMAYER, D.B. (2015). Rethinking forest carbon assessments to account for policy institutions. Nature Climate Change 5, 946-949.

Mackowski, C. M. (1987). Wildlife Hollows and Timber Management in Blackbutt Forest. Masters of Natural Resources thesis, University of New England.

Magnuson, W. E., LimA, A. P. \& DE LiMA, O. (1996). Group lightning mortality of trees in Neotropical forst. Journal of Tropical Ecology 12, 899-903.

Manning, A. D., Fischer, J., Felton, A., Newell, B., Steffen, W. \& Lindenmayer, D. B. (2009). Landscape fluidity - a unifying perspective for understanding and adapting to global change. Journal of Biogeography 36, 193-199.

Manning, A. D., Gibbons, P., Fischer, J., Oliver, D. L. \& Lindenmayer, D. B. (2013). Hollow futures? Tree decline, lag effects and hollow-dependent species. Animal Conservation 16, 395-403.

MAron, M. \& Fitzsimons, J. A. (2007). Agricultural intensification and loss of matrix habitat over 23 years in the West Wimmera, south-eastern Australia. Biological Conservation 135, 587-593.

Maron, M., Gordon, A., Mackey, B. G., Possingham, H. P. \& Watson, J. E. M. (2015). Conservation: Stop misuse of biodiversity offsets. Nature News 523, 401-403. 
Martin, K., AitKen, K. E. \& Wiebe, K. L. (2004). Nest sites and nest webs for cavity-nesting communities in interior British Columbia, Canada: nest characteristics and niche partitioning. Condor 106, 5-19.

Martinez-Ramos, M. \& Alvarez-Buylla, E. R. (1998). How old are tropical rain forest trees? Trends in Plant Science 3, 400-405.

Mazzei, L., Sist, P., Ruschel, A., Putz, F.E., Marco, P., Pena, W. \& Ferreira, J. (2010). Above-ground biomass dynamics after reduced-impact logging in the Eastern Amazon. Forest Ecology and Management 259, 367-373.

McAlpine, C. A., Syktus, J., Deo, R. C., Lawrence, P. J., McGowan, H. A., Watterson, I. G. \& PHINN, S. R. (2007). Modeling the impact of historial land cover change on Australia’s regional climate. Geophysical Research Letters 34, L22711.1-L22711.6.

MCKenNEY, H. J. \& KiRKPATRICK, J. B. (1999). The role of fallen logs in the regeneration of tree species in Tasmanian mixed forest. Australian Journal of Botany 47, 745-753.

MCNulty, S. A. \& MASTERS, R. D. (2005). Changes to the Adriondack Forest: implications of Beech bark disease on forest structure and seed production. In Beech bark disease: Proceedings of the Beech bark disease symposium (eds. C. A. Evans, J. A. Lucas and M. J. Tweny), pp. 52-57. USDA, General Technical Report NE-331, Newton Square, Pennslyvania.

Meir, P., Wood, T. E., Galbraith, D., Brando, P., Da Costa, A., Rowland, L. \& FERREIRA, L. V. (2015). Threshold responses to soil moisture deficit by trees and soil in tropical rain forests: Insights from field experiments. BioScience 65, 882-892.

Millar, C. I. \& StePHENSON, N. L. (2015). Temperate forest health in an era of emerging megadisturbance. Science 349, 823-826. 
Moe, S. R., Rutina, L. P., Hytteborn, H. \& DU Toit, J. T. (2009). What controls woodland regeneration after elephants have killed the big trees? Journal of Applied Ecology 46, $223-230$.

Moga, C.I., Samoila, C., Ollerer, K., Bancila, R.I., Reti, K.-O., Craiveanu, C., Poszet, S., RAKOSY, L., \& HARTEL, T. (2016). Environmental determinants of the old oaks in wood-pastures from a changing traditional social-ecological system of Romania. Ambio (in press).

Morrison, T. A., Holdo, R. M. \& Anderson, T. M. (2016). Elephant damage, not fire or rainfall, explains mortality of overstorey trees in Serengeti. Journal of Ecology 104, $409-418$.

Muller, F., BAesSler, C., Schubert, H. \& KlOtZ, S. (2011). Long-term ecological research. Between theory and application. Springer, Dordrecht.

Murcia, C., Aronson, J., Kattan, G. H., Moreno-Mateos, D., Dixon, K. \& Simberloff, D. (2014). A critique of the 'novel ecosystem' concept. Trends in Ecology \& Evolution 29, 548-553.

NASON, J. D. \& HAMRICK, J. L. (1997). Reproductive and genetic consequences of forest fragmentation: Two case studies of neotropical canopy trees. Journal of Heredity 88, $264-276$.

Nepstad, D. C., Tohver, I. M., Ray, D., Moutinho, P. \& Cardinot, G. (2007). Mortality of large trees and lianas following experimental drought in an Amazon forest. Ecology 88, 2259-2269.

NEWELL, G. R. (1999). Responses of Lumholtz's tree-kangaroo (Dendrolagus lumholtzi) to loss of habitat within a tropical rainforest fragment. Biological Conservation 91, 181189.

Newton, I. (1998). Population Limitation in Birds. Academic Press, London. 
Nilsson, S. G., Niklasson, M., Hedin, J., Aronsson, G., Gutowski, J. M., Linder, P., LjungBerg, H., Muikusinski, G. \& T., R. (2002). Densities of large living and dead trees in old-growth temprate and boreal forest. Forest Ecology and Management 161, 189-204.

Nilsson, S. G., Niklasson, M., Hedin, J., Eliasson, P. \& LJungberG, H. (2006). Biodiversity and sustainable forestry in chaning landscapes - principles and southern Sweden as an example. Journal of Sustainable Forestry 21, 11-43.

Nolke, N., Fehrmann, L., Jaya, I. N., Tiryana, T., Seidel, D. \& Kleinn, C. (2015). On the geometry and allometry of big-buttressed trees - a challenge for forest monitoring: new insights from 3D-modelling with terrestrial laser scanning. iForest 6, 574-581.

Osuri, A. M., Ratnam, J., Varma, V., Alvarez-Loayza, P., Astaiza, J. H., Bradford, M., Fletcher, C., Ndoundou-Hockemba, M., Janzen, P. A., Kenfack, D., Marshall, A. R., RAmesh, B. R., Rovero, F. \& SANKARAn, M. (2016). Contrasting effects of defaunation on aboveground carbon storage across the global tropics. Nature Communications, doi: 10.1038/ncomms11351.

Owen, J. (2008). Oldest living tree found in Sweden, vol. 2015. National Geographic News, http://news.nationalgeographic.com/news/2008/04/080414-oldest-tree.html.

Ozanne, C. M. P., Anhuf, D., Boulter, S. L., Keller, M., Kitching, R. L., Körner, C., Meinzer, F. C., Mitchell, A. W., Nakashizuka, T., Silva Dias, P. L., Stork, N. E., Wright, S. J. \& YoshimURA, M. (2003). Biodiversity meets the atmosphere: a global view of forest canopies. Science 301, 183.

Palik, B. J., Ostry, M. E., Venette, R. C. \& Abdela, E. (2011). Fraxinus nigra (black ash) dieback in Minnesota: regional variation and potential contributing factors. Forest Ecology and Management 261, 128-135. 
Pederson, N. (2010). External characteristics of old trees in the Eastern Deciduous forests. Natural Areas Journal 30, 396-407.

Penuelas, J. (2005). A big issue for trees. Nature 437, 965-966.

Pfautsch, S., Harbusch, M., Wesolowski, A., Smith, R., Macfarlane, C., TJoelker, M.G., REICH, P.B. \& ADAMS, M.A. (2016). Climate determines vascular traits in the ecologically diverse genus Eucalyptus. Ecology Letters 19, 240-248.

Phillips, N. G., Buckley, T. N. \& Tissue, D. T. (2008). Capacity of old trees to respond to environmental change. Journal of Integrative Plant Biology 50, 1355-1364.

PhILliPS, O. L. \& GENTRY, A. H. (1994). Increasing turnover through time in tropical forests. Science 263, 954-958.

Phillips, O. L., Malhi, Y., Higuchi, N., Laurance, W. F., NúÑEz, P. V., VÁsquez, R. M., Laurance, S. G., Ferreira, L. V., Stern, M., Brown, S. \& Grace, J. (1998). Changes in the carbon balance of tropical forests: evidence from long-term plots. Science 282, 439-442.

Platt, W. J., Doren, R. F. \& Armentano, T. V. (2000). Effects of Hurricane Andrew on stands of Slash Pine (Pinus elliottii var. densa) in the everglades region of south Florida (USA). Plant Ecology 146, 43-60.

PoOrter, L., Wright, S. J., PAZ, H., ACKerly, D. D., Condit, R., IbARrA-MANRiQuez, G., Harms, K. E., Licona, J. C., Martinez-Ramos, M., Mazer, S. J., Muller-Landau, H. C., Pena-Claros, M., Webb, C. O. \& Wright, I. J. (2008). Are functional traits good predictors of demographic rates? Ecology 89, 1908-1920.

PopkIN, G. (2015). Battling a giant killer. Science 349, 803-805.

Power, S., Delage, F., Chung, C., Kociuba, G. \& Keay, K. (2013). Robust twenty-firstcentury projections of El Nino and related precipitation variability. Nature 502, 541545. 
Punchi-Manage, R., Wiegand, T., Wiegand, K., Getzin, S., Huth, A., Gunatilleke, C. V. S. \& GunAtiLleKe, I. A. U. (2015). Neighborhood diversity of large trees shows independent species patterns in a mixed dipterocarp forest in Sri Lanka. Ecology 96, $1823-1834$.

Putz, F. E., Zuidema, P., Synnott, T., Pena-Claros, M., Pinard, M. A., Sheil, D., Vanclay, J., Sist, P., Gourlet-Fleury, S., Griscom, B., Palmer, J. \& Zagt, R. (2012). Sustaining conservation values in selectively logged tropical forests: the attained and the attainable. Conservation Letters 5, 296-303.

Raffa, K. F., Aukema, B. H., Bentz, B. J., Carroll, A. L., Hicke, J. A., Turner, M. G. \& Romme, W. H. (2008). Cross-scale drivers of natural disturbances prone to anthropogenic amplification: the dynamics of bark beetle eruptions. BioScience 58, $501-507$.

REDFORD, K. H. (1992). The empty forest. BioScience 42, 412-422.

REMm, J. \& LoHMUS, A. (2011). Tree cavities in forests - The broad distribution pattern of a keystone structure for biodiversity. Forest Ecology and Management 262, 579-585.

RICCIARDI, A. \& SimberlofF, D. (2008). Assisted colonization is not a viable conservation strategy. Trends in Ecology \& Evolution 24, 248-253.

Richardson, S. J., Smale, M. C., Hurst, J. M., Fitzgerald, N. B., Peltzer, D. A., Allen, R. B., Bellingham, P. J. \& MCKelvey, P. J. (2009). Large-tree growth and mortality rates in forests of the central North island, New Zealand. New Zealand Journal of Ecology 33, 208-215.

RoBerts, A. (1971). Birds of South Africa. John Voelcker Bird Book Fund, Cape Town, South Africa.

Romps, D. M., Seeley, J. T., Vollaro, D. \& Molinari, J. (2014). Projected increase in lightning strikes in the United States due to global warming. Science 346, 851-854. 
Rose, C., Marcot, B. G., Mellen, T. K., Ohmann, J. L., Waddell, K., Lindley, D. \& SCHREIBER, B. (2001). Decaying wood in Pacific Northwest forests: concepts and tools for habitat management. In Wildlife-Habitat Relationships in Oregon and Washington (ed. D. Johnson and T. O'Neil), pp. 580-623. Oregon State University Press, Corvallis.

Rowland, L., Da Costa, C. L., Galbriath, D. R., Oliveira, R. S., Binks, O. J., Oliveira, A. A., Pullen, A. M., Doughty, C. E., Metcalfe, D. B., Vasconcelos, H. L., Ferreira, L. V., Mahli, Y., Grace, J., Mencuccini, M. \& Meir, P. (2015). Death from drought in tropical forests is triggered by hydraulics not carbon starvation. Nature 528, 119-122.

Save the Redwoods League (2016). Protecting Redwood Forests. Save the Redwoods League, http://www.savetheredwoods.org/our-work/protect/.

SCHIERMEIER, Q. (2016). Pristine forest at risk,. Nature 530, 393.

Setterfield, S. A., Rossiter Rachor, N. A., Hutley, L. B., Douglas, M. M. \& Williams, R. J. (2010). Turning up the heat: the impacts of Andropogon gayanus (gamba grass) invasion on fire behaviour in northern Australian savannas Diversity and Distributions 16, 854-861.

Shore, T. L., Brooks, J. \& Stone, J. E. (2003). Mountain Pine Beetle Symposium: Challenges and Solutions, vol. Information Report BC-X-399 (ed. N. R. Canada). Canadian Forest Service and Pacific Forestry Centre, Victoria.

Sillett, S. C., van Pelt, R., Carroll, A. L., Kramer, R. D., Ambrose, A. R. \& Trask, D. (2015). How do tree structure and old age affect growth potential of California redwoods? Ecological Monographs 85, 181-212. 
Sillett, S. C., van Pelt, R., Koch, G. W., Ambrose, A. R., Carroll, A. L., Antoine, M. E. \& Mifsud, B. M. (2010). Increasing wood production through old age in tall trees. Forest Ecology and Management 259, 976-994.

Sist, P., MAZzEI, L., BLANC, L. \& RUtishauser, E. (2014). Large trees as key elements of carbon storage and dynamics after selective logging in the Eastern Amazon. Forest Ecology and Management 318, 103-109.

Slik, J. W. F., PaOli, G., McGuire, K., Amaral, I., Barroso, J., Bastian, M., Blanc, L., Bongers, F., Boundua, P., Clark, C., Collins, M., Dauby, G., Ding, Y., Doucet, J.-L., ELER, E., ET AL. (2013). Large trees drive forest aboveground biomass variation in lowland forests across the tropics. Global Ecology and Biogeography 22, 12611271.

Smith, A., Page, B., Duffy, K. \& Slotow, R. (2012). Using maximum entropy modeling to predict the potential distributions of large trees for conservation planning. Ecosphere $3,56$.

Smith, A. L., Blair, D., McBurney, L., Banks, S. C., Barton, P. S., Blanchard, W., Driscoll, D. A., Gill, A. M. \& LindenMayer, D. B. (2013). Dominant drivers of seedling establishment in a fire-dependent obligate seeder: climate or fire regimes? Ecosystems 17, 258-270.

Smith, A. L., Blanchard, W., Blair, D., McBurney, L., Banks, S. C., Driscoll, D. A. \& LINDENMAYER, D. B. (2016). The dynamic regeneration niche of a forest following a rare disturbance event. Diversity and Distributions 22, 457-467.

Stahlheber, K. A., Crispin, K. L., Anton, C. \& D'Antonio, C. M. (2015). The ghosts of trees past: savanna trees create enduring legacies in plant species composition. Ecology 96, 2510-2522. 
Stephenson, N. L., Das, A. J., Condit, R., Russo, S. E., BAKer, P. J., Beckman, N. G., Coomes, D. A., Lines, E. R., Morris, W. K., Rüger, N., Álvarez, E., Blundo, C., Bunyavejchewin, S., Chuyong, G., Davies, S. J., ET AL. (2014). Rate of tree carbon accumulation increases continuously with tree size. Nature 507, 90-93.

Stephenson, N. L., van Mantgem, P. J., Bunn, A. G., Bruner, H., Harmon, M. E., O'Connell, K. B., Urban, D. L. \& Franklin, J. F. (2011). Causes and implications of the correlation between forest productivity and tree mortality rates. Ecological Monographs 81, 527-555.

Stirzaker, R., Vertessey, R. \& SARre, A. (2002). Trees, Water and Salt. An Australian Guide to Using Trees for Healthy Catchments and Productive Farms. Joint Venture Agroforestry Program, Canberra.

TAYlor, C., McCARthy, M. A. \& LindenMAYER, D. B. (2014). Non-linear effects of stand age on fire severity. Conservation Letters 7, 355-370.

Tews, J., Brose, U., Grimm, V., Tielborger, K., Wilchmann, M., Schwager, M. \& JELTSCH, F. (2004). Animal species diversity driven by habitat heterogeneity/diversity: the importance of keystone structures. Journal of Biogeography 31, 79-92.

Thomas, R. Q., Kellner, J. R., Clark, D. B. \& PeART, D. R. (2013). Low mortality in tall tropical trees. Ecology 94, 920-929.

Thomas, S. C. (2011). Age-related changes in tree growth and functional biology: the role of reproduction. In Size- and age-related changes in tree structure and function (ed. F. C. Meinzer, B. Lachenbruch and T. E. Dawson), pp. 33-64. Springer Science+ Business Media. 
TnG, D. Y. P., Williamson, G. J., Jordan, G. J. \& Bowman, D. M. J. S. (2012). Giant eucalypts - globally unique fire-adapted rain-forest trees? New Phytologist 196, $1001-1014$.

TsEn, E. W. J., SitZiA, T. AND WEBBER, B. L. (2015), To core, or not to core: the impact of coring on tree health and a best-practice framework for collecting dendrochronological information from living trees. Biological Reviews. doi: $10.1111 /$ brv. 12200

Vanak, A. T., Shannon, G., Thaker, M., Page, B., Grant, R. \& Slotow, R. (2011). Biocomplexity in large tree mortality: interactions between elephant, fire and landscape in an African savanna. Ecography 35, 315-321.

Van Der Sleen, P., Groenenddijk, P., Vlam, M., Anten, N. P. R., Boom, A., Bongers, F., Pons, T. L., Terburg, G. \& Zuidema, P. (2015). No growth stimulation of tropical trees by 150 years of $\mathrm{CO}_{2}$ fertilization but water-use efficiency increased. Nature geoscience 8, 24-28.

van Kleunen, M., Dawson, W., Essl, F., Pergl, J., Winter, M., Weber, E., Kreft, H., Weigelt, P., Kartesz, J., Nishino, M., Antonova, L. A., Barcelona, J. F., Cabezas, F. J., Cardenas, D., Cardenas-Toro, J., ET AL. (2015). Global exchange and accumulation of non-native plants. Nature 525, 100-103.

van Mantgem, P. J., Stephenson, N. L., Byrne, J. C., Daniels, L. D., Franklin, J. F., Fule, P. Z., Harmon, M. E., Larson, A. J., Smith, J. M., Taylor, A. H. \& Veblen, T. T. (2009). Widespread increase of tree mortality rates in western United States. Science 323, 521-524.

VAN Pelt, R. (2008). Identifying Old Trees and Forests in Eastern Washington, pp. 166. Washington State Department of Natural Resources, Olympia, Washington. 
VAn Pelt, R. \& Sillett, S. C. (2008). Crown development of coastal Pseduotsuga menziesii including a conceptual model for tall conifers. Ecological Monographs 78, 283-311.

Voight, C. C., Borissov, I. \& Kelm, D. H. (2015). Bats fertilize roost trees. Biotropica 47, 403-406.

WARDELL-Johnson, G. (2016). EcoCheck: Australia's Southwest Jarrah forests have lost their iconic giants. In The Conversation https://theconversation.com/ecocheckaustralias-southwest-jarrah-forests-have-lost-their-iconic-giants-49150.

WARING, K. \& O'HARA, K. L. (2006). Estimating relative error in growth ring analyses of second-growth coast redwood (Sequoia sempervirens). Canadian Journal of Forest Research 36, 2216-2222.

WAssie, A., Sterck, F. J. \& Bongers, F. (2010). Species and structural diversity of church forests in a fragmented Ethiopian Highland landscape. Journal of Vegetation Science $21,938-948$.

WEBB, S. L. (1988). Windstorm damage and microsite colonization in two Minnesota forests. Canadian Journal of Forest Research 18, 1186-1195.

Weinberg, A., GibBons, P., Briggs, S. V. \& Bonser, S. P. (2011). The extent and pattern of Eucalyptus regeneration in an agricultural landscape. Biological Conservation 144, $227-233$.

Welsh, A.H., Cunningham, R.B., Donnelly, C.F. And LindenMayer, D.B. (1996). Modelling the abundance of rare species: statistical models for counts with extra zeros. Ecological Modelling, 88, 297-308.

WENK, E. H. \& FALSTER, D. S. (2015). Quantifying and understanding reproductive allocation schedules in plants. Ecology and Evolution 5, 5521-5538. 
Williams, R. J., Cook, G. D., Gill, A. M. \& Moore, P. H. R. (1999). Fire regime, fire intensity and tree survival in a tropical savanna in northern Australia. Australian Journal of Ecology 24, 50-59.

Winfield, C. \& Svenson, A. (2009). Saving the Giants. Department of Environment and Conservation, Perth, Western Australia.

Wood, S. W., HuA, Q., Allen, K. J. \& Bowman, D. M. J. S. (2010). Age and growth of a fire prone Tasmanian temperate old-growth forest stand dominated by Eucalyptus regnans, the world's tallest angiosperm. Forest Ecology and Management 260, 438447.

Wright, S. J., Zeballos, H., Domínguez, I., Gallardo, M. M., Moreno, M. C. \& IbÁÑEz, R. (2000). Poachers alter mammal abundance, seed dispersal, and seed predation in a neotropical forest. Conservation Biology 14, 227-239.

YARD, A. (2013). Laser beam uncovers giants of the forest. ABC News, http://www.abc.net.au/news/2013-04-11/laser-beam-uncovers-giants-of-theforest $/ 4624106$.

YORK, R. A. (2015). Large-tree removal in a mixed conifer forest halves productivity and increases white fir. California Agriculture January-March, 27-35.

YounG, I. R., ZIEGER, S. \& BABANIN, A. V. (2011). Global trends in wind speed and wave height. Science 332, 451-455.

YounG, T. P. \& HubBelL, S. P. (1991). Crown asymmetry, treefalls, and repeat disturbance of broad-leaved forest gaps. Ecology 72, 1464-1471.

Zuidema, P. A., Vlam, M. \& ChiEn, P. D. (2011). Ages and long-term growth patterns of four threatened Vietnamese tree species. Trees 25, 29-38. 


\section{SUPPORTING INFORMATION}

Additional supporting information may be found in the online version of this article.

Table S1. Summary of the wide range of key ecological roles played by large old trees. Large young trees, small young trees or small old trees either do not play these roles or the ecological function is impaired relative to large old trees.

Table S2. Key processes threatening populations of large old trees. The effects of climate change have been excluded as they may interact with or further magnify the effects of many of the processes listed in the table, such as drought, windstorms and fire as well as promote invasions of exotic species (see text). 
Table 1. The height and girth dimensions of the some of the world's largest old trees.

\begin{tabular}{|l|l|l|l|l|l|}
\hline & & & & & \\
\hline
\end{tabular}




\section{Figure legends}

Fig. 1. Large streamers of decorticating bark hanging from the lateral branches of large old mountain ash (Eucalyptus regnans) trees in Australia. These streamers are best developed on the largest trees in old-growth stands (Lindenmayer et al., 2000) and are an unstudied microhabitat for a rich array of invertebrate taxa such as flightless tree crickets (inset). Photographs by Esther Beaton.

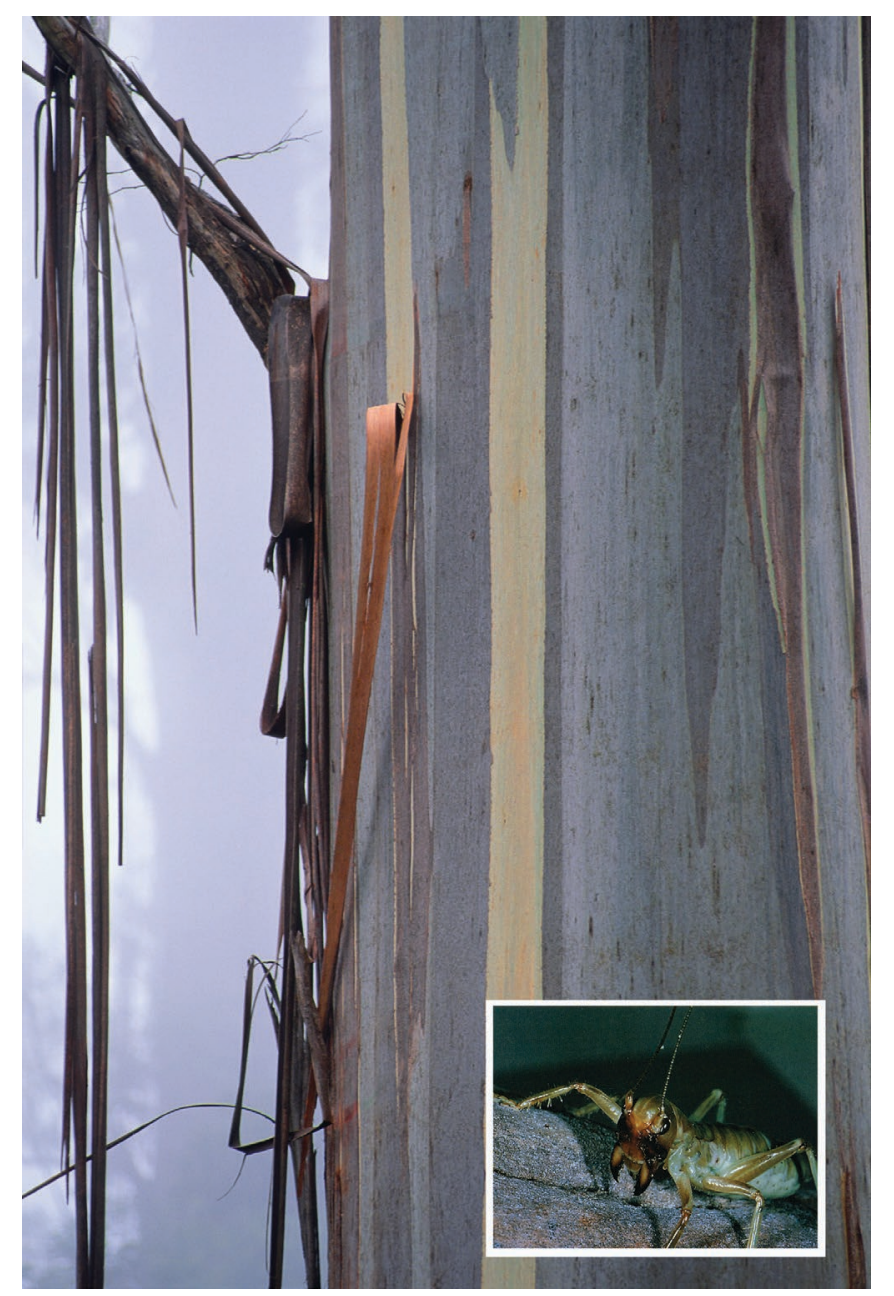

Fig. 2. Significant artworks featuring trees and modern-day photographs of their locations in Europe, North America and Asia. From top to bottom, left to right: Camille Covet's Florence vue depuis les jardins 1835 and image of modern-day Florence, Italy from the Bardini garden (photograph by G. Icoges); Van Gogh's Large Plane Trees 1889 and a modern-day tree-lined stretch in Saint-rémy-de-provence, France (photograph by S. Alamy); K. Hokusai's Mishima pass in Kai province (between 1826 and 1833) and a view to Mount Fuji from Kai Province, 
Japan (photograph by J. Riddy); Huc-Mazelet Luquiens' Banyan - Study etching 1922 and the

Banyan tree in Hawaii today (photograph by Wikicommons).
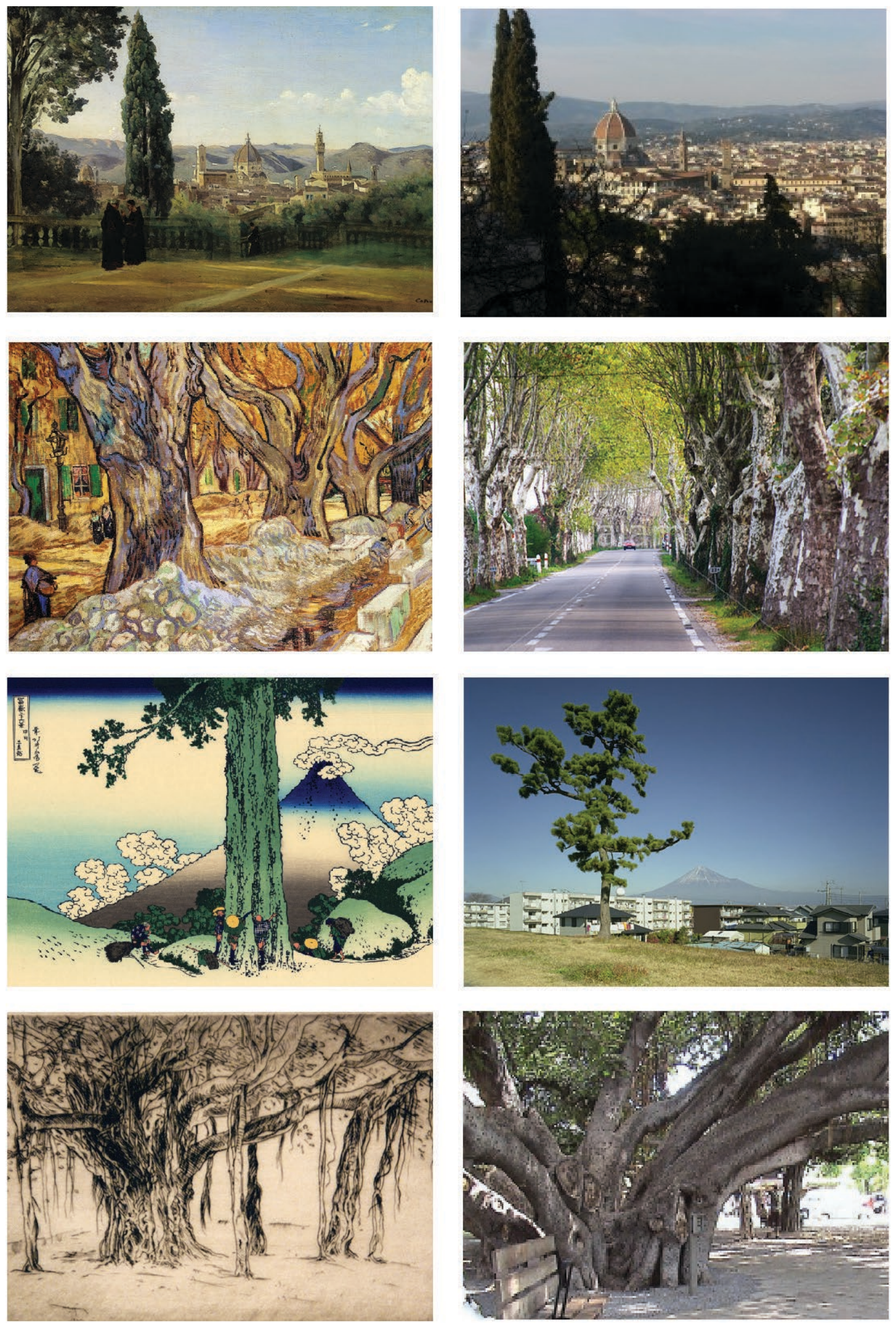
Fig. 3. A large old tree spreading sparks across a forest landscape in south-eastern Australia, highlighting the spatial footprint that these trees can have on their surrounding landscape and on key ecological processes. Photo by Jeff Cutting.

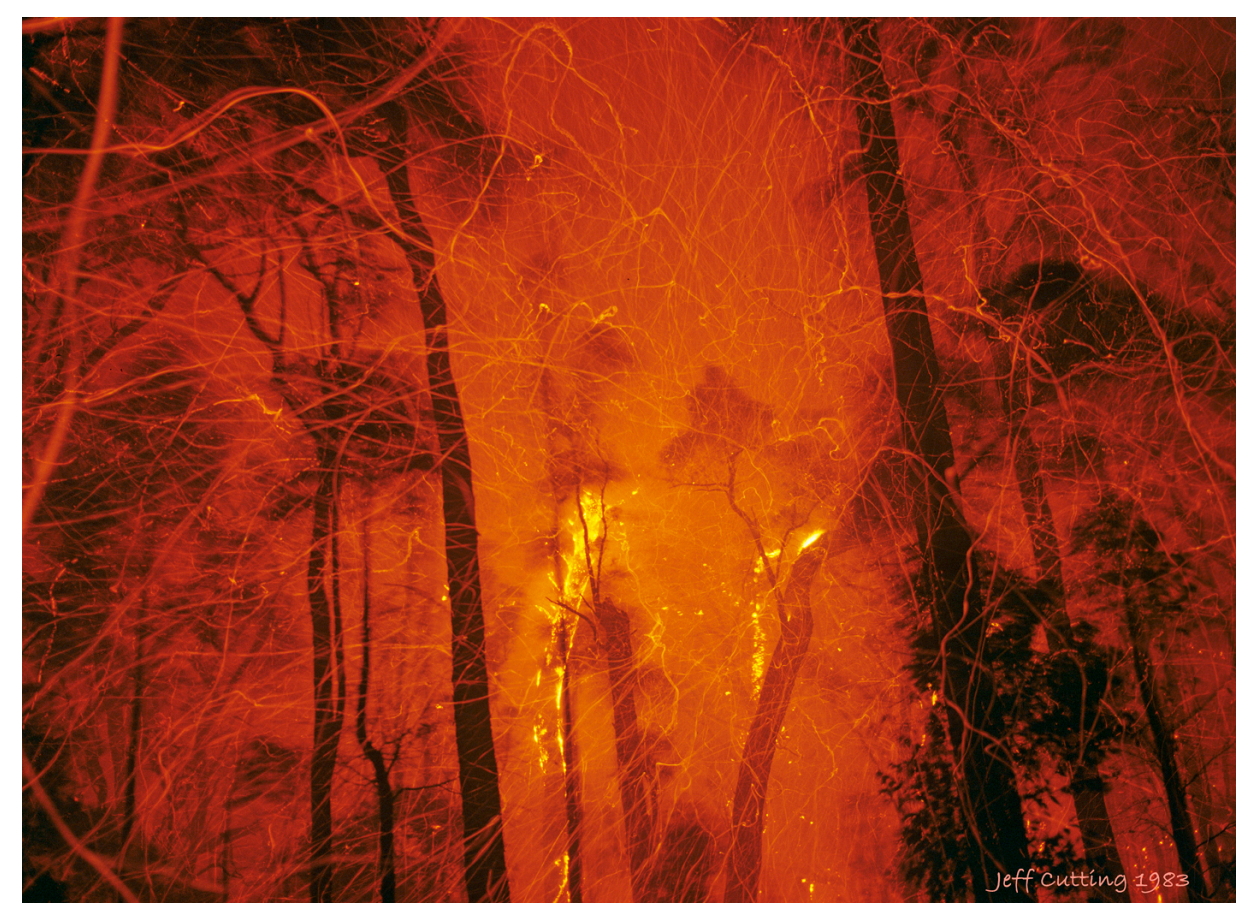

Fig. 4. Simple conceptual framework for identifying and tackling factors threatening populations of large old trees.

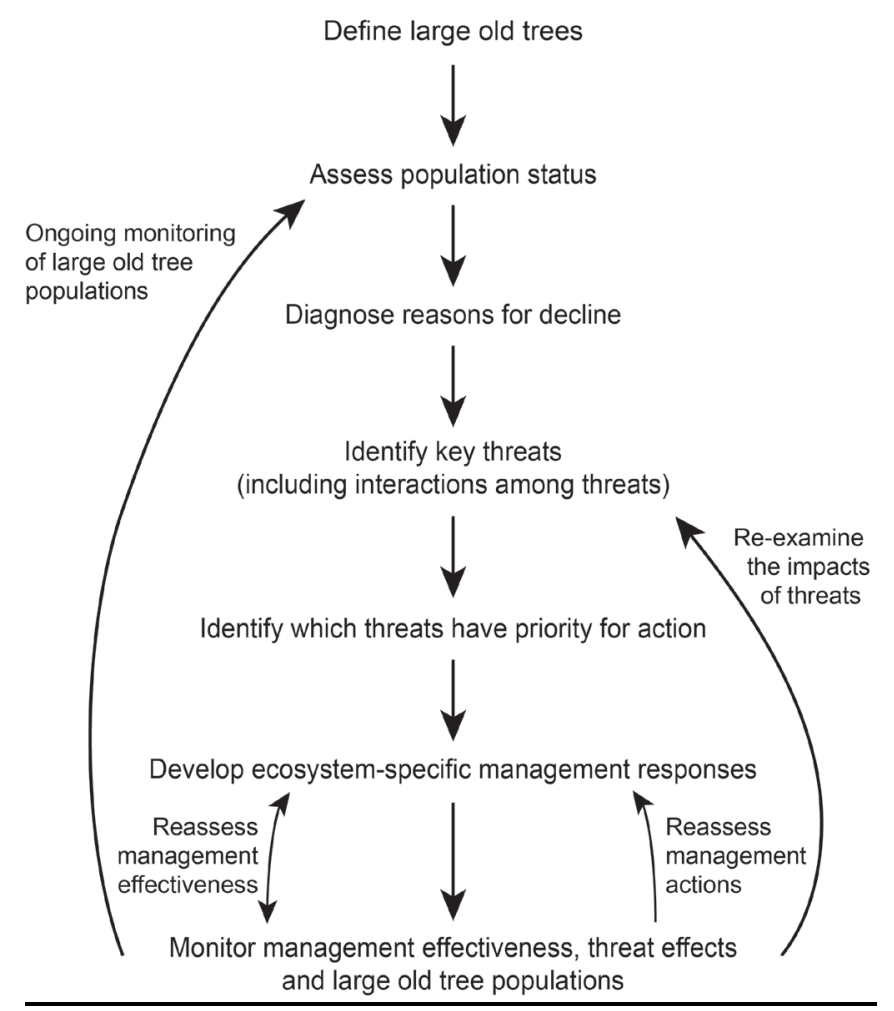




\section{Supporting Information}

Table S1. Summary of the wide range of key ecological roles played by large old trees. Large young trees, small young trees or small old trees either do not play these roles or the ecological function is impaired relative to large old trees.

\begin{tabular}{|c|c|c|}
\hline Ecological role & Description & Example citation/s \\
\hline $\begin{array}{l}\text { Vertically redistributing } \\
\text { nutrients in the soil } \\
\text { profile }\end{array}$ & $\begin{array}{l}\text { Deep roots bring carbon and other } \\
\text { nutrients to the surface from the } \\
\text { deep soil layers }\end{array}$ & $\begin{array}{l}\text { Attiwill and Leeper (1987) } \\
\text { Ludwig et al. (2004) }\end{array}$ \\
\hline $\begin{array}{l}\text { Spatially redistributing } \\
\text { nutrients through } \\
\text { importation }\end{array}$ & $\begin{array}{l}\text { Large old trees can promote } \\
\text { importation of nutrients through } \\
\text { attracting animals leading to } \\
\text { altered localized soil fertility }\end{array}$ & Dean et al. (1999) \\
\hline $\begin{array}{l}\text { Contributing to nitrogen } \\
\text { budgets }\end{array}$ & $\begin{array}{l}\text { Epiphytic bryophytes and } \\
\text { cyanobacteria on the trunks and } \\
\text { lateral branches of large old trees } \\
\text { play important roles in nitrogen } \\
\text { fixation and can contribute to } \\
\text { long-term site productivity }\end{array}$ & Lindo and Whiteley (2011) \\
\hline $\begin{array}{l}\text { Tapping deep } \\
\text { groundwater resources }\end{array}$ & $\begin{array}{l}\text { The extensive root systems of } \\
\text { large old trees can tap } \\
\text { groundwater resources and } \\
\text { influence hydrological regimes } \\
\text { (including processes of secondary } \\
\text { salinity) }\end{array}$ & $\begin{array}{l}\text { Nepstad et al. (1994) } \\
\text { Stirzaker et al. (2002) }\end{array}$ \\
\hline $\begin{array}{l}\text { Altering rainfall } \\
\text { interception }\end{array}$ & $\begin{array}{l}\text { Large old trees with large } \\
\text { canopies alter rainwater } \\
\text { throughput to soils and water } \\
\text { infiltration into the soil }\end{array}$ & $\begin{array}{l}\text { Poppenborg and Holscher } \\
\underline{(2009)}\end{array}$ \\
\hline $\begin{array}{l}\text { Altering microclimatic } \\
\text { environments }\end{array}$ & $\begin{array}{l}\text { Large old trees can significantly } \\
\text { alter local microclimatic } \\
\text { conditions, for example, by } \\
\text { shading the ground for animals }\end{array}$ & Dean et al. (1999) \\
\hline $\begin{array}{l}\text { Altering mesoclimatic } \\
\text { conditions }\end{array}$ & $\begin{array}{l}\text { Large old trees can be important } \\
\text { for evapotranspiration because } \\
\text { their large amount of foliage and } \\
\text { deep root systems permit } \\
\text { photosynthesis in drier months } \\
\text { when smaller trees have to cease } \\
\text { growing; their contributions to } \\
\text { cloud formation and dry-season } \\
\text { rainfall might be critical in some } \\
\text { tropical ecosystems }\end{array}$ & Nepstad et al. (1994) \\
\hline
\end{tabular}




\begin{tabular}{|c|c|c|}
\hline $\begin{array}{l}\text { Increase nutrient } \\
\text { availability }\end{array}$ & $\begin{array}{l}\text { The presence of root systems } \\
\text { (including associated } \\
\text { mycorrhizae) in a given layer } \\
\text { tends (in general) to increase } \\
\text { mineralisation of nutrients from } \\
\text { organic to inorganic form, in part } \\
\text { due to higher microbial activity } \\
\text { around roots but also other factors } \\
\text { and processes }\end{array}$ & Attiwill and Leeper (1987) \\
\hline $\begin{array}{l}\text { Providing habitat for } \\
\text { other plants and fungi }\end{array}$ & $\begin{array}{l}\text { Large old trees provide physical } \\
\text { substrates for other plants such as } \\
\text { epiphytic angiosperms, mistletoe } \\
\text { and bryophytes }\end{array}$ & $\begin{array}{l}\underline{\text { Kartzinel et al. (2013) }} \\
\text { Thor et al. (2010) } \\
\text { Watson (2001) }\end{array}$ \\
\hline $\begin{array}{l}\text { Having competitive and } \\
\text { suppressive effects on } \\
\text { other plants }\end{array}$ & $\begin{array}{l}\text { Large old trees can have } \\
\text { significant localized competitive } \\
\text { and suppressive effects on other } \\
\text { plant species and act as organizers } \\
\text { of tree demography through } \\
\text { competition }\end{array}$ & $\begin{array}{l}\underline{\text { Fauset et al. (2015) }} \\
\text { Lutz et al. (2013) } \\
\text { Punchi-Manage et al. (2015) }\end{array}$ \\
\hline $\begin{array}{l}\text { Promoting of the } \\
\text { growth of sub-canopy } \\
\text { plants }\end{array}$ & $\begin{array}{l}\text { Nutrient and propagule hotspots } \\
\text { created by animal visitation to } \\
\text { large old trees can promote } \\
\text { growth in other plants }\end{array}$ & $\begin{array}{l}\text { Jayasekara et al. (2007) } \\
\text { Neilan et al. (2006) }\end{array}$ \\
\hline $\begin{array}{l}\text { Contributing to Above } \\
\text { Ground Biomass and } \\
\text { carbon stocks }\end{array}$ & $\begin{array}{l}\text { Large old trees are a small } \\
\text { proportion of the number of stems } \\
\text { in a stand but large contributor to } \\
\text { carbon biomass }\end{array}$ & $\begin{array}{l}\text { Clark and Clark (1996) } \\
\underline{\text { Slik et al. (2013) }}\end{array}$ \\
\hline $\begin{array}{l}\text { Acting as sources of } \\
\text { large pieces of coarse } \\
\text { woody debris }\end{array}$ & $\begin{array}{l}\text { Large lateral branches and other } \\
\text { parts of trees play many important } \\
\text { ecological roles when they fall } \\
\text { and become part of the ground } \\
\text { layer architecture }\end{array}$ & $\begin{array}{l}\text { Harmon et al. (1986) } \\
\text { Killey et al. (2010) }\end{array}$ \\
\hline $\begin{array}{l}\text { Providing critical } \\
\text { wildlife habitat }\end{array}$ & $\begin{array}{l}\text { The cavities and other key } \\
\text { structures provided by large old } \\
\text { trees provide critical denning, } \\
\text { roosting, nesting sites for a wide } \\
\text { range of fauna }\end{array}$ & $\begin{array}{l}\underline{\text { Fischer and McClelland }} \\
\underline{(1983)} \\
\underline{\text { Gibbons and Lindenmayer }} \\
\underline{(2002)} \\
\underline{\text { Remm and Lohmus (2011) }}\end{array}$ \\
\hline $\begin{array}{l}\text { Acting as key sites for } \\
\text { animal social behaviour }\end{array}$ & $\begin{array}{l}\text { Large old trees can be focal points } \\
\text { for social interactions of species } \\
\text { such as aggregations of snakes or } \\
\text { leks for mammals }\end{array}$ & $\begin{array}{l}\text { Cockburn and Lazenby- } \\
\text { Cohen }(1992)\end{array}$ \\
\hline
\end{tabular}




\begin{tabular}{|c|c|c|}
\hline $\begin{array}{l}\text { Providing a source of } \\
\text { water-filled cavities for } \\
\text { a range of animal } \\
\text { species }\end{array}$ & $\begin{array}{l}\text { The cavities in large old trees can } \\
\text { fill with water and provide } \\
\text { breeding sites for frogs and } \\
\text { invertebrates such as mosquitoes. } \\
\text { Some vertebrates also may drink } \\
\text { from these water sources }\end{array}$ & $\underline{\text { Wells }(2010)}$ \\
\hline $\begin{array}{l}\text { Acting as short-term } \\
\text { micro-refuges for } \\
\text { animals }\end{array}$ & $\begin{array}{l}\text { Large old trees can be important } \\
\text { refuges which allow animals to } \\
\text { survive the immediate effects of } \\
\text { fire }\end{array}$ & Brennan et al. (2011) \\
\hline $\begin{array}{l}\text { Providing key sources } \\
\text { of food for animals }\end{array}$ & $\begin{array}{l}\text { Pulses of flowers, seeds, fruit on } \\
\text { large old trees are critical food } \\
\text { resources for a wide range of } \\
\text { animals }\end{array}$ & Felton et al. (2010) \\
\hline $\begin{array}{l}\text { Contributing to vertical } \\
\text { habitat heterogeneity in } \\
\text { vegetation cover }\end{array}$ & $\begin{array}{l}\text { Large old trees affect the three- } \\
\text { dimensional structure of } \\
\text { vegetation via negative correlation } \\
\text { between crown density and } \\
\text { understory-plant density. This } \\
\text { can, in turn, have major impacts } \\
\text { on foraging and breeding niche } \\
\text { availability for a range of species } \\
\text { groups }\end{array}$ & $\begin{array}{l}\underline{\text { Bernard (2001) }} \\
\text { Brokaw and Lent (1999) } \\
\text { Brown et al. (1997) } \\
\text { Terborgh (1980) }\end{array}$ \\
\hline $\begin{array}{l}\text { Contributing to spatial } \\
\text { habitat heterogeneity in } \\
\text { vegetation cover }\end{array}$ & $\begin{array}{l}\text { Large old trees influence spatial } \\
\text { patterns of water, nutrients, } \\
\text { structures and processes leading } \\
\text { to distinct patterns of spatial } \\
\text { heterogeneity in habitat suitability } \\
\text { at multiple spatial scales }\end{array}$ & $\begin{array}{l}\text { Dean et al. (1999) } \\
\text { Vanak et al. (2011) }\end{array}$ \\
\hline $\begin{array}{l}\text { Contributing to } \\
\text { connectivity and } \\
\text { movement }\end{array}$ & $\begin{array}{l}\text { Large old trees act as stepping } \\
\text { stones to facilitate animal and } \\
\text { plant movement in landscapes }\end{array}$ & $\begin{array}{l}\text { Plieninger et al. (2015) } \\
\text { Fischer and Lindenmayer } \\
\underline{(2002)}\end{array}$ \\
\hline $\begin{array}{l}\text { Acting as propagule } \\
\text { hotspots }\end{array}$ & $\begin{array}{l}\text { Large old trees can act as hotspots } \\
\text { for propagule arrival via seed- } \\
\text { dispersing animals attracted to big } \\
\text { trees }\end{array}$ & Neilan et al. (2006) \\
\hline $\begin{array}{l}\text { Acting as a source of } \\
\text { pollinators for the rest } \\
\text { of the landscape }\end{array}$ & $\begin{array}{l}\text { Populations of vertebrate (e.g. } \\
\text { bats) and invertebrate (e.g. bees) } \\
\text { pollinators attracted to large old } \\
\text { trees can contribute a } \\
\text { disproportionately significant } \\
\text { pollination service to surrounding } \\
\text { areas }\end{array}$ & Arthur et al. (2010) \\
\hline
\end{tabular}




\begin{tabular}{|c|c|c|}
\hline $\begin{array}{l}\text { Providing key sources } \\
\text { of propagules }\end{array}$ & $\begin{array}{l}\text { Large old trees often } \\
\text { reproductively dominant, } \\
\text { contributing disproportionate } \\
\text { numbers of germinants to new } \\
\text { cohorts of plant recruits in } \\
\text { surrounding areas. For example, } \\
\text { they can act as major nodes of } \\
\text { regeneration for woodland and } \\
\text { forest in agricultural areas }\end{array}$ & $\begin{array}{l}\underline{\text { Fischer et al. (2009) }} \\
\underline{\text { Smith et al. (2013) }} \\
\underline{\text { Weiner et al. (2009) }} \\
\text { Wenk and Falster (2015) }\end{array}$ \\
\hline $\begin{array}{l}\text { Influencing local and } \\
\text { landscape disturbance } \\
\text { processes and dynamics }\end{array}$ & $\begin{array}{l}\text { Large old trees can be attractants } \\
\text { for lightning strikes and affect } \\
\text { spatial contagion in fire dynamics } \\
\text { through being a source of sparks } \\
\text { during fires. They create major } \\
\text { canopy gaps when they fall as tree } \\
\text { height is a predictor of gap size }\end{array}$ & $\begin{array}{l}\underline{\text { Crowe et al. (1984) }} \\
\text { Brown et al. (1997) } \\
\text { Magnuson et al. (1996) }\end{array}$ \\
\hline $\begin{array}{l}\text { Acting as indicators or } \\
\text { surrogates of } \\
\text { environmental change }\end{array}$ & $\begin{array}{l}\text { Large old trees can provide key } \\
\text { information about environmental } \\
\text { change such as changes in } \\
\text { groundwater as a consequence of } \\
\text { salinization of declining water } \\
\text { tables }\end{array}$ & Stirzaker et al. (2002) \\
\hline
\end{tabular}


Table S2. Key processes threatening populations of large old trees. The effects of climate change have been excluded as they may interact with or further magnify the effects of many of the processes listed in the table, such as drought, windstorms and fire as well as promote invasions of exotic species (see text).

\begin{tabular}{|c|c|c|}
\hline Process & $\begin{array}{l}\text { Descriptions of example } \\
\text { responses }\end{array}$ & Example citations \\
\hline Windstorms & $\begin{array}{l}\text { Windstorms can } \\
\text { disproportionately affect large old } \\
\text { trees }\end{array}$ & $\begin{array}{l}\text { Lugo (2008) } \\
\text { Webb (1988) }\end{array}$ \\
\hline Fire & $\begin{array}{l}\text { Wildfires can disproportionately } \\
\text { affect large old trees }\end{array}$ & Lindenmayer et al. (2012) \\
\hline Drought & $\begin{array}{l}\text { Drought events have significantly } \\
\text { greater negative effects on large } \\
\text { old trees than on smaller trees }\end{array}$ & $\begin{array}{l}\text { Bennett et al. (2015) } \\
\text { Rowland et al. (2015) }\end{array}$ \\
\hline Insect attack & $\begin{array}{l}\text { Pest invertebrate outbreaks such } \\
\text { as pine beetles can have greatest } \\
\text { impacts on large old trees }\end{array}$ & $\begin{array}{l}\text { Kashian et al. (2011) } \\
\text { Shore et al. (2003) }\end{array}$ \\
\hline $\begin{array}{l}\text { Large vertebrate } \\
\text { herbivores }\end{array}$ & $\begin{array}{l}\text { Large herbivores such as } \\
\text { elephants damage trees with } \\
\text { interacting effects of fire and } \\
\text { fungal attack }\end{array}$ & $\begin{array}{l}\text { Moe et al. (2009) } \\
\text { Vanak et al. (2011) }\end{array}$ \\
\hline Land clearing & $\begin{array}{l}\text { Billions of trees, including large } \\
\text { old trees, are removed as part of } \\
\text { widespread vegetation clearing for } \\
\text { agriculture, land conversion (e.g. } \\
\text { for plantations), urban } \\
\text { development }\end{array}$ & Crowther et al. (2015) \\
\hline $\begin{array}{l}\text { Over-browsing by } \\
\text { domestic livestock }\end{array}$ & $\begin{array}{l}\text { Intensive grazing pressure by } \\
\text { domestic livestock impairs the } \\
\text { recruitment of large old trees }\end{array}$ & $\begin{array}{l}\text { Fischer et al. (2009) } \\
\text { Gibbons et al. (2008) }\end{array}$ \\
\hline Logging & $\begin{array}{l}\text { Some kinds of logging operations } \\
\text { can disproportionately target large } \\
\text { old trees, or trees retained at the } \\
\text { time of harvesting can } \\
\text { subsequently be killed or } \\
\text { destroyed in stand regeneration } \\
\text { fires }\end{array}$ & $\begin{array}{l}\text { Lindenmayer et al. (1990) } \\
\text { York (2015) }\end{array}$ \\
\hline $\begin{array}{l}\text { Landscape } \\
\text { fragmentation }\end{array}$ & $\begin{array}{l}\text { Large old trees can be susceptible } \\
\text { to premature death or collapse } \\
\text { following clearing of forest in the } \\
\text { surrounding landscape }\end{array}$ & Laurance et al. (2000) \\
\hline
\end{tabular}




\begin{tabular}{l|l|l}
\hline Invasive plant species & $\begin{array}{l}\text { Invasive plant species may alter } \\
\text { fire regimes that badly damage } \\
\text { large old trees or preclude the } \\
\text { recruitment of new cohorts of } \\
\text { large old trees }\end{array}$ & Setterfield et al. (2010) \\
\hline Invasive animal species & $\begin{array}{l}\text { Exotic animals such as introduced } \\
\text { pest insects can have significant } \\
\text { effects on tree species and stands, } \\
\text { including populations of large old } \\
\text { trees }\end{array}$ & $\begin{array}{l}\text { McNulty and Masters } \\
\text { (2005) }\end{array}$ \\
Popkin (2015) \\
\hline Pathogens & $\begin{array}{l}\text { Introduced pathogens can kill or } \\
\text { badly damage entire stands of } \\
\text { trees including large old trees }\end{array}$ & $\begin{array}{l}\text { (www.kauricoast.co.nz/feat } \\
\text { ure.cfm?wpid=6337). }\end{array}$ \\
\hline $\begin{array}{l}\text { Increased populations } \\
\text { of parasites }\end{array}$ & $\begin{array}{l}\text { Large old trees may be susceptible } \\
\text { to the impacts of increased } \\
\text { parasite loads (e.g. lianas) }\end{array}$ & Laurance et al. (2013) \\
\hline $\begin{array}{l}\text { The establishment of } \\
\text { human infrastructure }\end{array}$ & $\begin{array}{l}\text { Large old trees are often cleared } \\
\text { to establish infrastructure such as } \\
\text { roads }\end{array}$ & Forman (2014) \\
\hline
\end{tabular}

\section{References}

Arthur, A.D., Lia, J., Henrya, S., Cunningham, S.A. 2010. Influence of woody vegetation on pollinator densities in oilseed Brassica fields in an Australian temperate landscape. 11, 406414.

Attiwill, P.M., Leeper, G.W. 1987. Forest soils and nutrient cycling. Melbourne University Press, Melbourne.

Bennett, A.C., McDowell, N.G., Allen, C.D., Anderson-Teixeira, K.J. 2015. Larger trees suffer most during drought in forests worldwide. 1, Article no. 15139.

Bernard, E. 2001. Vertical stratification of bat communities in primary forests of Central Amazon, Brazil. 17, 115-126.

Brennan, K., Moir, M.L., Wittkuhn, R.S. 2011. Fire refugia: the mechanism governing animal survivorship within a highly flammable plant. $36,131-141$.

Brokaw, N.V., Lent, R.A. 1999. Vertical structure, in Hunter, M. (editor, Managing Biodiversity in Forest Ecosystems. Cambridge University Press, Cambridge, pp. 373-399 
Brown, G.W., Nelson, J.L., Cherry, K.A. 1997. The influence of habitat structure on insectivorous bat activity in montane ash forests of the Central Highlands of Victoria. Australian Forestry 60, 138-146.

Clark, D.B., Clark, A.C. 1996. Abundance, growth and mortality of very large trees in neotropical lowland rain forest. Forest Ecol Manage 80, 235-244.

Cockburn, A., Lazenby-Cohen, K.A. 1992. Use of nest trees by Antechinus stuartii, a semelparous lekking marsupial. Journal of Zoology London, 226, 657-680.

Crowe, M.P., Paxton, J., Tyers, G. 1984. Felling dead trees with explosives. 47, 84-87. Crowther, T.W., Glick, H.B., Covey, K.R., Bettigole, C., Maynard, D.S., Thomas, S.M., Smith, J.R., Hintler, G., Duguid, M.C., Amatulli, G., Tuanmu, M.-N., Jetz, W., Salas, C., Stam, C., Piotto, D., Tavani, R., Green, S., Bruce, G., Williams, S.J., Wiser, S.K., Huber, M.O., Hengeveld, G.M., Nabuurs, G.-J., Tikhonova, E., Borchardt, P., Li, C.-F., Powrie, L.W., Fischer, M., Hemp, A., Homeier, J., Cho, P., Vibrans, A.C., Umunay, P.M., Piao, S.L., Rowe, C.W., Ashton, M.S., Crane, P.R., Bradford, M.A. 2015. Mapping tree density at a global scale. 525, 201-205.

Dean, W.R., Milton, S.J., Jeltsch, F. 1999. Large trees, fertile islands, and birds in arid savanna. 41,61-78.

Fauset, S., Johnson, M.O., Gloor, M., Baker, T.R., Monteagudo, A., Brienen, R.J.W., Feldpausch, T.R., Lopez-Gonzalez, G., Malhi, Y., ter Steege, H., Pitman, N.C.A., Baraloto, C., Engel, J., Petronelli, P., Andrade, A., al., e. 2015. Hyperdominance in Amazonian forest carbon cycling. 6,6857 .

Felton, A.M., Felton, A., Foley, W.J., Lindenmayer, D.B. 2010. The role of timber tree species in the nutritional ecology of spider monkeys in a certified logging concession, Bolivia. 259, 1642-1649. 
Fischer, J., Lindenmayer, D.B. 2002. The conservation value of paddock trees for birds in a variegated landscape in southern New South Wales. 2. Paddock trees as stepping stones. 11, 833-849.

Fischer, J., Stott, J., Zerger, A., Warren, G., Sherren, K., Forrester, R.I. 2009. Reversing a tree regeneration crisis in an endangered ecoregion. 106, 10386-10391.

Fischer, W.C., McClelland, B.R. 1983. Cavity-nesting bird bibiography including related titles on forest snags, fire, insects, diseases and decay. Intermountain Forest and Range Experiment Station, Ogden, Utah.

Forman, R.T. 2014. Urban ecology. Cambridge University Press, Cambridge, England.

Gibbons, P., Lindenmayer, D.B. 2002. Tree Hollows and Wildlife Conservation in Australia. CSIRO Publishing, Melbourne.

Gibbons, P., Lindenmayer, D.B., Fischer, J., Manning, A.D., Weinberg, A., Seddon, J., Ryan, P., Barrett, G. 2008. The future of scattered trees in agricultural landscapes. 22, 1309-1319. Harmon, M., Franklin, J.F., Swanson, F., Sollins, P., Gregory, S.V., Lattin, J.D., Anderson, N.H., Cline, S.P., Aumen, N.G., Sedell, J.R., Lienkaemper, G.W., Cromack, K., Cummins, K. 1986. Ecology of coarse woody debris in temperate ecosystems. Advances in Ecological Research 15, 133-302.

Jayasekara, P., Weerasinghe, U.R., Wijesundara, S., Takatsuki, S. 2007. Identifying duirnal of nocturnal frugivores in the terrestrial and arboreal layers of a tropical forest in Sri Lanka. $13,7-15$.

Kartzinel, T.R., Trapnell, D.W., Shefferson, R.P. 2013. Critical importance of large native trees for conservation of a rare Neotropical epiphyte. 101, 1429-1438.

Kashian, D.M., Jackson, R.M., Lyons, H.D. 2011. Forest structure altered by mountain pine beetle outbreaks affects subsequent attack in a Wyoming lodgepole pine forest, USA. 41, 2403-2412. 
Killey, P., McElhinny, C., Rayner, I., Wood, J. 2010. Modelling fallen branch volumes in a temperate eucalypt woodland: implications for large senescent trees and benchmark loads of coarse woody debris. 35, 956-968.

Laurance, W.F., Andrade, A.S., Magrach, A., Camargo, J.L.C., Valsko, J.J., Campbell, M., Fearnside, P.M., Edwards, W., Lovejoy, T.E., Laurance, S.G. 2013. Long-term changes in liana abundance and forest dynamics in undisturbed Amazonian forests. 95, 1604-1611. Laurance, W.F., Delamonica, P., Laurance, S.G., Vasconcelos, H.L., Lovejoy, T.E. 2000. Rainforest fragmentation kills big trees. 404, 836.

Lindenmayer, D.B., Blanchard, W., McBurney, L., Blair, D., Banks, S., Likens, G.E., Franklin, J.F., Stein, J., Gibbons, P. 2012. Interacting factors driving a major loss of large trees with cavities in an iconic forest ecosystem. PLOS One 7, e41864.

Lindenmayer, D.B., Cunningham, R.B., Tanton, M.T., Smith, A.P. 1990. The conservation of arboreal marsupials in the montane ash forests of the Central Highlands of Victoria, southeast Australia: II. The loss of trees with hollows and its implications for the conservation of Leadbeater's Possum Gymnobelideus leadbeateri McCoy (Marsupialia: Petauridae). 54, 133145.

Lindo, Z., Whiteley, J.A. 2011. Old trees contribute bio-available nitrogen through canopy bryophytes. $342,141-148$.

Ludwig, F., de Kroon, H., Berendse, F., Prins, H.H. 2004. The influence of savanna trees on nutrient, water and light availability and the understory vegetation. 170, 93-105. Lugo, A. 2008. Visible and invisible effects of hurricanes on forest ecosystems: an international review. 33, 368-398.

Lutz, J.A., Larson, A.J., Freund, J.A., Swanson, M.E., Bible, K. 2013. The importance of large-diameter trees to forest structural heterogeneity. . 8, e82784. 
Magnuson, W.E., Lima, A.P., de Lima, O. 1996. Group lightning mortality of trees in Neotropical forst. 12, 899-903.

McNulty, S.A., Masters, R.D. 2005. Changes to the Adriondack Forest: Implications of Beech bark disease on forest structure and seed production. pp. 52-57 in Evans, C.A., Lucas, J.A., Tweny, M.J. editors. Beech bark disease: Proceedings of the Beech bark disease symposium. USDA, General Technical Report NE-331, Newton Square, Pennslyvania. Moe, S.R., Rutina, L.P., Hytteborn, H., du Toit, J.T. 2009. What controls woodland regeneration after elephants have killed the big trees? 46, 223-230.

Neilan, W., Catterall, C.P., Kanowski, J., McKenna, S. 2006. Do frugivorous birds assist rainforest succession in weed dominated oldfield regrowth of subtropical Australia? 129, 393-407.

Nepstad, D.C., Crane, M., Carvalho, C.R., Davidson, E.A., Jipp, P.H., Lefebvre, P.A., Negreiros, G.H., da Silva, E.D., Stone, J.E., Trumbore, S.E., Viera, S. 1994. The role of deep roots in the hydrological and carbon cycles of Amazonian forests and pastures. 372, 666669.

Plieninger, T., Levers, C., Mantel, M., Costa, A., Schaich, H., Kuemmerle, T. 2015. Patterns and drivers of scattered tree loss in agricultural landscapes: orchard meadows in Germany (1968-2009). 10, e0126178.

Popkin, G. 2015. Battling a giant killer. 349, 803-805.

Poppenborg, P., Holscher, D. 2009. Influence of emergent trees on rainfall distribution in a Cacao agroforest (Sulawesi, Indonesia). 204, 730-736.

Punchi-Manage, R., Wiegand, T., Wiegand, K., Getzin, S., Huth, A., Gunatilleke, C.V.S., Gunatilleke, I.A.U. 2015. Neighborhood diversity of large trees shows independent species patterns in a mixed dipterocarp forest in Sri Lanka. 96, 1823-1834. 
Remm, J., Lohmus, A. 2011. Tree cavities in forests - The broad distribution pattern of a keystone structure for biodiversity. 262, 579-585.

Rowland, L., da Costa, C.L., Galbriath, D.R., Oliveira, R.S., Binks, O.J., Oliveira, A.A., Pullen, A.M., Doughty, C.E., Metcalfe, D.B., Vasconcelos, H.L., Ferreira, L.V., Mahli, Y., Grace, J., Mencuccini, M., Meir, P. 2015. Death from drought in tropical forests is triggered by hydraulics not carbon starvation. 528, 119-122.

Setterfield, S.A., Rossiter Rachor, N.A., Hutley, L.B., Douglas, M.M., Williams, R.J. 2010. Turning up the heat: the impacts of Andropogon gayanus (gamba grass) invasion on fire behaviour in northern Australian savannas. 16, 854-861.

Shore, T.L., Brooks, J., Stone, J.E., editors. 2003. Mountain Pine Beetle Symposium: Challenges and Solutions. Canadian Forest Service and Pacific Forestry Centre, Victoria. Slik, J.W.F., Paoli, G., McGuire, K., Amaral, I., Barroso, J., Bastian, M., Blanc, L., Bongers, F., Boundja, P., Clark, C., Collins, M., Dauby, G., Ding, Y., Doucet, J.-L., Eler, E., Ferreira, L., Forshed, O., Fredriksson, G., Gillet, J.-F., Harris, D., Leal, M., Laumonier, Y., Malhi, Y., Mansor, A., Martin, E., Miyamoto, K., Araujo-Murakami, A., Nagamasu, H., Nilus, R., Nurtjahya, E., Oliveira, Á., Onrizal, O., Parada-Gutierrez, A., Permana, A., Poorter, L., Poulsen, J., Ramirez-Angulo, H., Reitsma, J., Rovero, F., Rozak, A., Sheil, D., Silva-Espejo, J., Silveira, M., Spironelo, W., ter Steege, H., Stevart, T., Navarro-Aguilar, G.E., Sunderland, T., Suzuki, E., Tang, J., Theilade, I., van der Heijden, G., van Valkenburg, J., Van Do, T., Vilanova, E., Vos, V., Wich, S., Wöll, H., Yoneda, T., Zang, R., Zhang, M.-G., Zweifel, N. 2013. Large trees drive forest aboveground biomass variation in lowland forests across the tropics. 22, 1261-1271.

Smith, A.L., Blair, D., McBurney, L., Banks, S.C., Barton, P.S., Blanchard, W., Driscoll, D.A., Gill, A.M., Lindenmayer, D.B. 2013. Dominant drivers of seedling establishment in a fire-dependent obligate seeder: climate or fire regimes? 17, 258-270. 
Stirzaker, R., Vertessey, R., Sarre, A., editors. 2002. Trees, Water and Salt. An Australian Guide to Using Trees for Healthy Catchments and Productive Farms. Joint Venture Agroforestry Program, Canberra.

Terborgh, J.W. 1980. Vertical stratification of a neotropical forest bird community. pp. 10051012. Proceedings of the XVII International Ornithological Conference.

Thor, G., Johansson, P., Jonsson, M.T. 2010. Lichen diversity and red-listed lichen species relationships with tree species and diameter in wooded meadows. 19, 2307-2328.

Vanak, A.T., Shannon, G., Thaker, M., Page, B., Grant, R., Slotow, R. 2011. Biocomplexity in large tree mortality: interactions between elephant, fire and landscape in an African savanna. $35,315-321$.

Watson, D.M. 2001. Mistletoe - A keystone resource in forests and woodlands worldwide. $32,219-249$.

Webb, S.L. 1988. Windstorm damage and microsite colonization in two Minnesota forests. $18,1186-1195$.

Weiner, J., Campbell, L.G., Pino, J., Echarte, L. 2009. The allometry of reproduction within plant populations. $97,1220-1233$.

Wells, K.D. 2010. Ecology and behavior of amphibians. University of Chicago Press, Chicago, USA.

Wenk, E.H., Falster, D.S. 2015. Quantifying and understanding reproductive allocation schedules in plants. 5, 5521-5538.

York, R.A. 2015. Large-tree removal in a mixed conifer forest halves productivity and increases white fir. January-March, 27-35. 